\title{
Isolation of the $\mathrm{Rb}$-related $\mathrm{p} 130$ through its interaction with CDK2 and cyclins
}

\author{
Gregory J. Hannon, Douglas Demetrick, and David Beach ${ }^{1}$ \\ Howard Hughes Medical Institute, Cold Spring Harbor Laboratory, Cold Spring Harbor, New York 11724 USA
}

\begin{abstract}
A two-hybrid protein interaction screen was used to isolate cDNAs encoding human proteins that can interact with human CDK2 in yeast. A new member of the retinoblastoma susceptibility gene family, Rbr-2 (Rb-related), was obtained. The sequence of the Rbr-2 protein shares $\sim 50 \%$ identity with $\mathbf{p} 107$ and homology to $\mathbf{R} \bar{b}$ within the pocket domain. Several lines of evidence indicate that Rbr- 2 is the adenovirus E1A-associated p130. Like Rb and $\mathrm{p} 107, \mathrm{p}^{130^{\mathrm{Rbr}-2}}$ can bind to viral oncoproteins, SV40 large $\mathrm{T}$ antigen, and adenovirus E1A through its pocket domain. Although $\mathrm{p} 130^{\mathrm{Rbr}-2}$ does not bind to $\mathrm{CDK} 2$ in vitro, it can interact with cyclins, with a clear preference for D-type cyclins. Because both CDK2 and $\mathrm{p} 130^{\mathrm{Rbr}-2}$ show affinity for cyclins, we suggest that $\mathrm{p} 130^{\mathrm{Rbr}-2}$ and $\mathrm{CDK} 2$ interacted through a yeast-derived cyclin bridge in the two-hybrid screen. The gene encoding $\mathrm{p} 130^{\mathrm{Rbr}-2}$ mapped to $16 \mathrm{q} 13$, a region of frequent genomic alteration in human tumors.
\end{abstract}

[Key Words: p130 ${ }^{\mathrm{Rbr}-2}$; CDK2; cyclins; E1A; Rb; two-hybrid screen]

Received August 5, 1993; revised version accepted September 29, 1993.

Passage of a mammalian cell through the cell cycle is regulated at a number of key control points. Among these are the points of entry into and exit from quiescence $\left(G_{0}\right)$, the restriction point, the $G_{1} / S$ transition, and the $G_{2} / M$ transition (for review, see Draetta 1990; Sherr 1993). For a cell to pass through a control point and enter the next phase of the cell cycle, it must complete all of the events of the preceding cell cycle phase and, in addition, satisfy a number of checkpoint controls. Such controls act, for example, to ensure that DNA replication has been successfully completed before the onset of mitosis. Ultimately, information from these checkpoint controls is integrated through the regulated activity of a group of related kinases, the cyclin-dependent kinases (CDKs). Once a phase of the cell cycle has been successfully completed, phosphorylation of critical substrates by activated CDKs allows passage of a cell cycle transition point and execution of the next cell cycle phase.

To date, five members of the CDK family have been identified in human cells; these are cdc2 (CDK1), CDK2, CDK3, CDK4, and CDK5 (for review, see Draetta 1990; Sherr 1993). These kinases are active only if complexed with a member of a family of positive regulatory subunits known as cyclins. D-type cyclins and cyclin $\mathrm{E}$ have been implicated in the regulation of the cell cycle during $G_{1}$ (Baldin et al. 1993; Ohtsubo and Roberts 1993). Cell

${ }^{1}$ Corresponding author. cycle kinase complexes that control passage through $\mathrm{G}_{1}$ are of particular interest because their regulation may link cell cycle control to the control of proliferation and differentiation. In this regard, the product of the retinoblastoma susceptibility gene $(R b)$ acts as a negative regulator of cell proliferation and may be involved in coupling proliferative signals to cell cycle control. Although the level of $\mathrm{Rb}$ protein remains constant throughout the cell cycle, $\mathrm{Rb}$ undergoes cyclic variations in its phosphorylation state. In quiescent cells or cells in early $\mathrm{G}_{1}, \mathrm{Rb}$ is present in a hypophosphorylated state. As cells progress toward the $G_{1} / S$ boundary, the overall level of $R b$ phosphorylation increases, and $\mathrm{Rb}$ is maintained in a hyperphosphorylated state through the following $\mathrm{S}, \mathrm{G}_{2}$, and $M$ phases (for review, see Goodrich and Lee 1993; Muller et al. 1993). Circumstantial evidence that Rb phosphorylation is necessary for transit through the cell cycle comes from studies in which $\mathrm{Rb}$ was overexpressed in SAOS- 2 cells that contain no endogenous $\mathrm{Rb}$. These cells appeared to arrest in $G_{1}$ and contained hypophosphorylated Rb (for review, see Muller et al. 1993). Ectopic expression of cyclins A or E, or D-type cyclins, could abrogate the growth suppressive effect of $R b$, and lack of growth suppression was often accompanied by the induction of $\mathrm{Rb}$ hyperphosphorylation (for review, see Muller et al. 1993). In addition, $\mathrm{Rb}$ binds D-type cyclins in vitro and in vivo (Dowdy et al. 1993; Kato et al. 1993) and can be phosphorylated by cyclin D/CDK4 kinases at sites of $\mathrm{Rb}$ phosphorylation in vivo (Kato et al. 1993). The data from these investigations support a model in 
which the ability of $\mathrm{Rb}$ to inhibit cell cycle progression is regulated by its phosphorylation by CDKs.

Studies of a large number of tumors and transformed cell lines suggest that loss of $\mathrm{Rb}$ function leads to a deregulation of growth and plays a substantial role in the expression of the neoplastic phenotype (for review, see Weinberg 1992). In this regard, Rb is targeted by the transforming proteins of a number of DNA tumor viruses. SV40 T antigen, adenovirus E1A, and HPV-16 E7 protein each bind to and possibly sequester hypophosphorylated forms of $\mathrm{Rb}$ (for review, see Muller et al. 1993). The ability to bind to viral oncoproteins is a defining characteristic of the $\mathrm{Rb}$ family of "pocket" proteins. Three additional proteins, p107, p130, and p300, have been tentatively grouped with $\mathrm{Rb}$ in this family. Each of these proteins was found in association with adenovirus E1A, and certain monoclonal antibodies against $\mathrm{Rb}$ can recognize other potential family members (Harlow et al. 1986; Hu et al. 1991). A cDNA encoding pl07 has been isolated, and this protein shows significant homology to $\mathrm{Rb}$ within the $\mathrm{Rb}$ pocket domain (Ewen et al. 1991; Zhu et al. 1993). p107 also shares with $\mathrm{Rb}$ the ability to bind to cyclins. p107 complexes with cyclins A and E in vivo and can bind cyclins D2 and D3 in vitro (Ewen et al. 1992, 1993; Faha et al. 1992; Lees et al. 1992).

It is becoming evident that progress through the cell cycle is governed by the association of multiple proteins into stable and metastable complexes. The identification and characterization of proteins that can interact with CDKs promise to increase our understanding of the spe- cific roles of CDKs in cell cycle regulation and the mechanisms by which the kinases themselves are regulated. One approach toward identifying proteins that can interact with CDKs is a technique known as the two-hybrid protein interaction screen (Fields and Song 1989). Here, we have used this screen to search for genes whose protein products can interact with CDK2. We have isolated one known gene, cks1 (a human suc1 homolog), and two previously unidentified genes. One of these genes encodes a new member of the $\mathrm{Rb}$ family of pocket proteins. Several lines of evidence indicate that this $\mathrm{Rb}$ relative is the ElA-associated p130.

\section{Results}

\section{Isolation of CDK2-binding proteins}

To identify previously uncharacterized proteins with roles in the regulation of transit through the $G_{1}$ and $S$ phases of the cell cycle, we sought to isolate cDNAs whose protein products could interact with the cell cycle regulatory kinase CDK2. Toward this goal, we employed a two-hybrid protein interaction screening procedure similar to that originally described by Fields and Song (1989; for review, see Bartel et al. 1993; see Fig. 1A). As a target for the two-hybrid screen, we fused the entire open reading frame of human CDK2 (Tsai et al. 1991) to the Gal4 DNA-binding domain in a vector that directs a low level of fusion protein expression in yeast. The tester strain for the screen, YPB2 (Bartel et al. 1993), contained two Gal4-inducible markers, HIS3 and lacZ (see Fig. 1A).

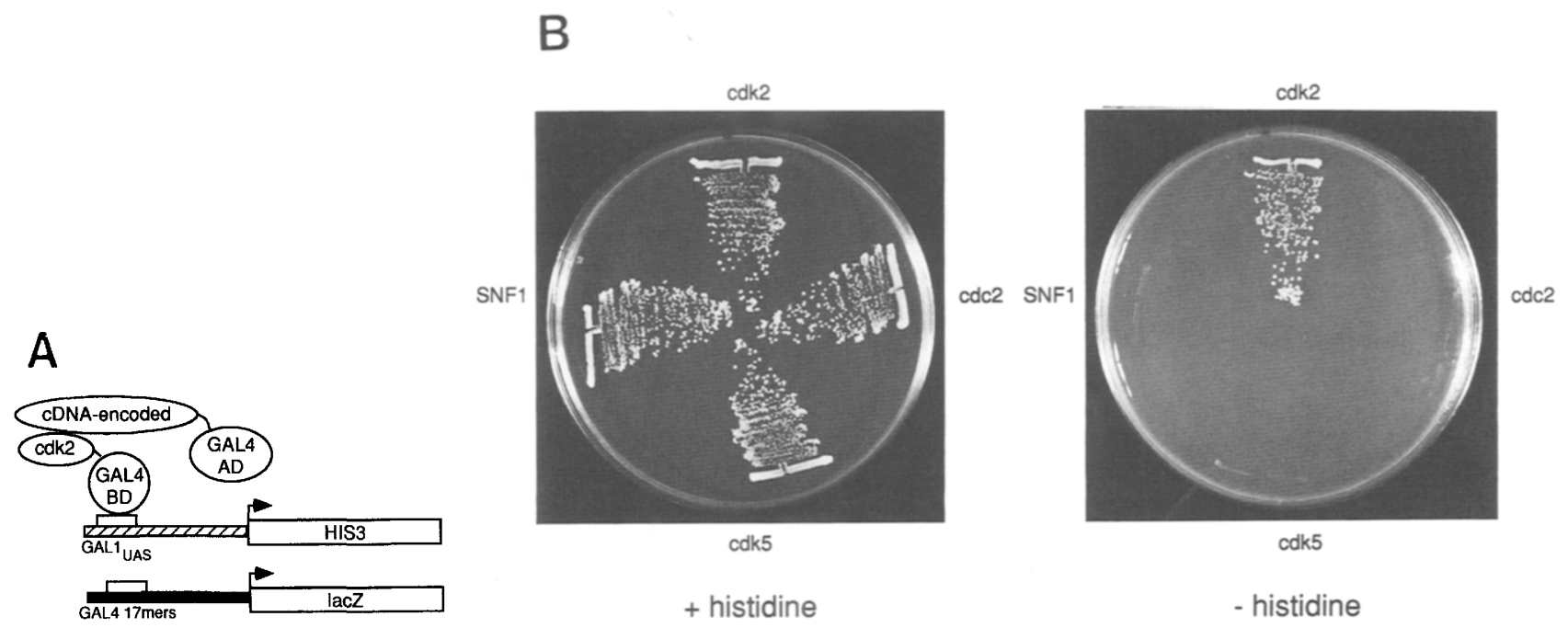

Figure 1. Two-hybrid screen with human CDK2. (A) A schematic representation of the interaction between the Gal4 DNA-binding domain $(\mathrm{BD})-\mathrm{CDK} 2$ fusion protein and a Gal4 activation domain $(\mathrm{AD})$ fusion with a cDNA-encoded protein. This interaction is shown to target the activation domain to two different Gal4-dependent promoters with consequent activation of the transcription of the HIS3 and lacZ marker genes. $(B)$ Yeast strain YPB2 containing plasmids expressing the Gal4 activation domain-p130 $0^{\mathrm{Rbr}-2}$ fusion in combination with plasmids expressing a Gal4 DNA-binding domain fused to either human CDK2, human cdc2, human CDK5, or $S$. cerevisiae SNFl. (+ histidine) The plate lacks only leucine and tryptophan and thus selects only for the presence of the activation domain and DNA-binding domain plasmids. (- histidine) The plate lacks leucine, tryptophan, and histidine and contains $30 \mathrm{~mm} 3-\mathrm{AT}$ (see Materials and methods), thus selecting not only for the presence of the two plasmids but also for the interaction of the plasmidencoded fusion proteins. 
This tester strain was cotransformed with the CDK2 interaction target and a HeLa cell cDNA library constructed in $\mathrm{PGAD}-\mathrm{GH}$, a vector that directs the synthesis of fusions between cDNA-encoded polypeptides and the Gal4 transcriptional activation domain. In cases where an activation domain fusion protein interacted with the CDK2 target, a functional Gal4 activity was reconstituted and expression of the two marker genes was activated.

Primary positives were selected by identifying colonies that could grow in the absence of histidine. Whereas transformation with the target alone gave no $\mathrm{His}^{+}$colonies, cotransformation of the target and the library produced a small number of colonies that were phenotypically His ${ }^{+}$. The majority of $\mathrm{His}^{+}$colonies were found to express $\beta$-galactosidase activity, and library plasmids were recovered from each of these positive strains. Library plasmids were used to retransform the tester strain in combination with either the original target or control plasmids. In the majority of cases, expression of the HIS3 and lac $Z$ markers was seen only in the presence of the CDK2 target and not in the presence of plasmids encoding a fusion between the Gal4 DNA-binding domain and the Saccharomyces cerevisiae SNF1 protein kinase.

To date, three classes of specific, positive clones have been analyzed. One class was composed of a number of related library plasmids, all of which encoded fusions between the Gal4 activation domain and cksl (Richardson et al. 1990), a human homolog of the Schizosaccharomyces pombe sucl protein. In fission yeast, sucl interacts tightly with the cdc2 protein kinase and is a subunit of active cdc2 kinase complexes (Brizuela et al. 1987). A second class of positive clones consisted of multiple isolates of plasmids encoding fusions between the Gal4 activation domain and a previously unknown protein that we have termed KAP (CDK-associated phosphatase). KAP was found to be a protein phosphatase that shows dual specificity for phosphotyrosine and phosphoserine residues (G. Hannon, D. Casso, and D. Beach, in prep.). The third class of positive clones was represented by a single isolate, which we termed $\mathrm{Rbr}-2$ (see below). This library plasmid contained a cDNA insert of $\sim 4.8 \mathrm{~kb}$ that, upon retransformation into YPB2, activated HIS3 and $l a c Z$ gene expression only in the presence of the Gal4 DNA-binding domain-CDK2 fusion and not in the presence of cdc2 or CDK5 target fusions (Fig. 1B).

\section{Rbr-2 is the E1A-associated p130, a new member of the $\mathrm{Rb}$ gene family}

Sequence analysis of the clone termed Rbr- 2 revealed an open reading frame of $\sim 3.3 \mathrm{~kb}$ fused to the Gal4 transcriptional activation domain. The predicted amino acid sequence derived from this open reading frame was used to search available data bases using the BLAST program on the NCBI blast network server (Altschul et al. 1990). Rbr-2 was found to have clear homology to two related proteins: p107 and Rb. It was on the basis of this homology that we chose the name Rbr-2 (Rb-related). Homology is greatest to the p107 protein sequence; Rbr-2 and p107 share $\sim 50 \%$ amino acid identity. Homology between $\mathrm{Rbr}-2$ and $\mathrm{Rb}$ is mainly confined to regions of $\mathrm{Rb}$ that are conserved between Rb and p107 (see Fig. 3, below; Ewen et al. 1991).

Homology to $\mathrm{Rb}$ and p107 clearly placed Rbr-2 within the $\mathrm{Rb}$ gene family and suggested the possibility that our Rbr- 2 cDNA might be a partial clone of p130 or $\mathrm{p} 300$, the two proteins that have also been tentatively placed in the $\mathrm{Rb}$ family on the basis of their physical properties (see above). Northern analysis indicated that the message corresponding to the Rbr-2 cDNA was $\sim 5 \mathrm{~kb}$ in length. Because this seemed insufficient to encode $\mathrm{p} 300$, we further investigated the possible relationship between Rbr-2 and p130.

We raised a polyclonal antiserum to a 71-amino-acid peptide that is unique to the Rbr- 2 sequence (amino acids 757-828 of Rbr-2; see Figs. 2 and 3). This antiserum specifically recognized $\mathrm{Rbr}-2$ and did not cross-react with $\mathrm{Rb}$ or $\mathrm{p} 107$. In immunoprecipitations from extracts of ${ }^{35} \mathrm{~S}$-labeled human cells, the Rbr- 2 antiserum recognized polypeptides that migrated as a diffuse band with roughly the same mobility as the E1A-associated p130 (data not shown). In addition, when proteins that coimmunoprecipitate with E1A were released from the precipitate and reimmunoprecipitated with the Rbr- 2 antiserum, p130 was specifically recovered (Fig. 4). Considered together, these results suggested that we had isolated a partial cDNA encoding the ElA-associated pl30. This was further confirmed by comparison of the Rbr- 2 sequence with the sequence of the p130 cDNA independently isolated by $\mathrm{Li}$ et al. (this issue). The remainder of the p130 cDNA was amplified by PCR from the HeLa cell cDNA library using nested primers derived from the Gal4 activation domain and the Rbr-2 sequence present in the initial clone (see Materials and methods). The complete coding sequence of $\mathrm{p} 130$ and the predicted amino acid sequence of the $\mathrm{p} 130$ protein are shown in Figure 2.

Comparison of the amino acid sequences of p107 and $\mathrm{Rb}$, in addition to a number of functional studies, has provided an outline of the shared domain structure of this protein family (Hu et al. 1990; Huang et al. 1990; Kaelin et al. 1990; Ewen et al. 1991). Binding of $\mathrm{Rb}$ and pl07 to the viral oncoproteins T antigen and ElA is mediated through the pocket domains of Rb and p107 (so named because this domain serves as an internal receptor for these viral proteins; Kaelin et al. 1990,1991; Ewen et al. 1991). The pocket is composed of two subdomains, $A$ and $B$, which are necessary and sufficient for viral protein binding. The A and B subdomains are separated by a

Figure 2. Sequence of $\mathrm{p} 130^{\mathrm{Rbr}-2}$. The DNA sequence of the coding region of the $\mathrm{p} 130^{\mathrm{Rbr}-2} \mathrm{cDNA}$, as well as the predicted amino acid sequence of the $\mathrm{p} 130^{\mathrm{Rbr}-2}$ protein, is shown. 


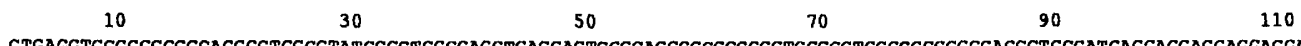
CTGAGGTCCGGCCGCCCAGGGGTGCGCTATGCCGTCGGGAGGTGACCAGTCGCCACCGCCCCCGCCTCCCCCTCCGGCGGCGGCAGCCTCGGATGAGGAGGAGGAGGACGACGGCGAGGC $\begin{array}{llllllllllllllllllllllllllllllll}M & \text { P } & S & G & G & D & Q & S & P & P & P & P & P & P & P & P & A & A & A & A & S & D & E & E & E & E & D & D & G & E & A\end{array}$

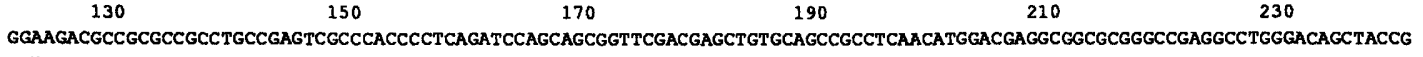

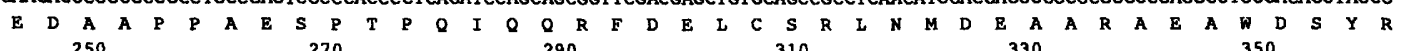
CAGCATGAGCGAAAGCTACACGCTGGAGGGAAATGATCTTCATTGGTTAGCATGTGCCTTATATGTGGCTTGCAGAAAATCTGTTCCAACTGTAAGCAAAGGGACAGTGGAAGGAAACTA

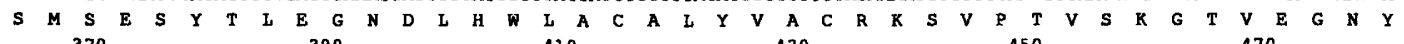
$\begin{array}{llllllll}370 & 390 & 410 & 430 & 450 & 470\end{array}$

TGTATCTTTAACTAGAATCCTGAAATGTTCAGAGCAGAGCTTAATCGAATTTTTTAATAAGATGAAGAAGTGGGAAGACATGGCAAATCTACCCCCACATTTCAGAGAACGTACTGAGAG

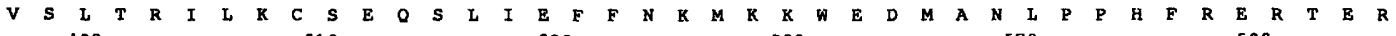
$490 \quad 510 \quad 530 \quad 550 \quad 590$

ATTAGAAAGAAACTTCACTGTTTCTGCTGTAATTTTTAAGAAATATGAACCCATTTTTCAGGACATCTTTAAATACCCTCAAGAGGAGCAACCTCGTCAGCAGCGAGGAAGGAAACAGCG

$\begin{array}{llllllllllllllllllllllllllllllllllllllll}I & E & R & N & F & T & V & S & A & V & I & F & K & K & Y & E & P & I & F & Q & D & I & F & K & Y & P & Q & B & E & Q & P & R & Q & Q & R & G & R & K & Q & R\end{array}$

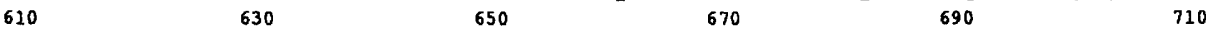

GCGACAGCCCTGTACTGTGTCTGAAATTTTCCATTTTTGTTGGGTGCTTTFTATATATGCAAAAGGTAATTTCCCCATGATTAGTGATGATTTGGTCAATTCTTATCACCTGCTGCTGTG

$\begin{array}{llllllllllllllllllllllllllllllllllllllllll}R & Q & P & C & T & \text { V } & S & E & I & F & H & F & C & W & V & L & F & I & Y & A & K & G & N & F & P & M & I & S & D & D & I & V & \text { N } & S & Y & H & L & L & L & C\end{array}$ $\underset{730}{P}$ C T V S E I F

TGCTTTGGACTTAGTTTATGGAAATGCACTTCAGTGTTCTAATCGTAAAGAACTTGTGAACCCTAATTTTAAAGGCTTATCTGAAGATTTTCATGCTAAAGATTCTAAACCTTCCTCTGA

$\begin{array}{llllllllllllllllllllllllllllllllllllllll}A & L & D & L & V & Y & G & N & A & L & Q & C & S & N & R & K & E & L & V & N & P & N & F & K & G & L & S & E & D & F & H & A & K & D & S & K & P & S & S & D\end{array}$ $850 \quad 870 \quad 890 \quad 910 \quad 830 \quad 950$

CCCCCCTTGTATCATTGAGAAACTGTGTTCCTTACATGATGGCCTAGTTTTGGAAGCAAAGGGGATAAAGGAACATTTCTGGAAACCCTATATTAGGAAACTTTATGAAAAAAAGCTCCT P P $\begin{gathered}\text { C C I I I E } \\ 970\end{gathered}$

TAAGGGAAAAGAAGAAAATCTCACTGGGTTTCTAGAACCTGGGAACTTTGGAGAGAGTTTTAAAGCCATCAATAAGGCCTATGAGGAGTATGTTTTATCTGTTGGGAATTTAGATGAGCG

$\begin{array}{lllllllllllllllllllllllllllllllllllllllllll}K & G & K & E & E & N & \text { L } & T & G & F & \text { I } & E & P & G & N & F & G & B & S & F & K & A & I & N & K & A & Y & E & E & Y & V & L & S & V & G & N & L & D & E & R\end{array}$

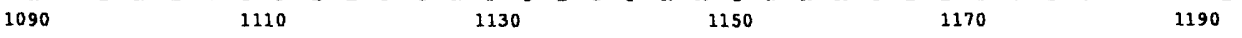

GATATTTCTTGGAGAGGATGCTGAGGAGGAAATTGGGACTCTCTCAAGGTGTCTGAACGCTGGTTCAGGAACAGAGACTGCT GAAAGGGTGCAGATGAAAAACATCTTACAGCAGCATTT

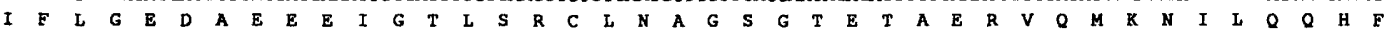

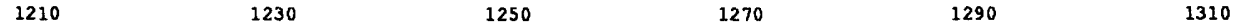

TGACAAGTCCAAAGCACTTAGAATCTCCACACCACTAACTGGTGTTAGGTACATTAAGGAGAATAGCCCTTGTGTGACTCCAGTTTCTACAGCTACGCATAGCTTGAGTCGTCTTCACAC

$\begin{array}{llllllllllllllllllllllllllllllllllllllll}D & R & S & K & A & L & R & I & S & T & P & L & T & G & V & R & Y & I & K & E & N & S & P & C & V & T & P & V & S & T & A & T & H & S & L & S & R & L & H & T\end{array}$ $\begin{array}{ccccccccc}1330 & 1350 & 1370 & 1390 & 1410 & 1430\end{array}$

CATGCTGACAGGCCTCAGGAATGCACCAAGTGAGAAACT GGAACAGATTCTCAGGACATGTTCCAGAGATCCAACCCAGGCTATTGC TAACAGACTGAAAGAAATGTT TGAAATATATTC

$\begin{array}{llllllllllllllllllllllllllllllllllllllllllll}M & L & T & G & L & R & N & A & P & S & E & K & L & E & Q & I & L & R & T & C & S & R & D & P & T & Q & A & I & A & N & R & L & R & E & M & F & E & I & Y & S\end{array}$

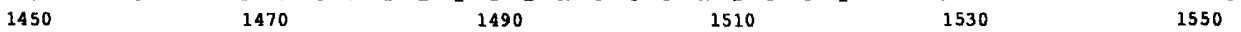

TCAGCATTTCCAGCCAGACGAGGATTTCAGTAATTGTGCTAAAGAAATTGCCAGCAAACATTTTCGTTTTGCGGAGATGCTTTACTATAAAGTATTAGAATCTGTTATTGAGCAGGAACA

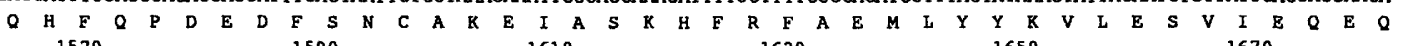
$\begin{array}{llllll}1570 & 1590 & 1610 & 1630 & 1650 & 1670\end{array}$

AAAAAGACTAGGAGACATGGATTTATCTGGTATTCTGGAACAAGATGCGTTCCACAGATCTCTCTTGGCCTGCTGCCTTGAGGTCGTCACTTTTTCTTATAAGCCTCCTGGGAATTTTCC

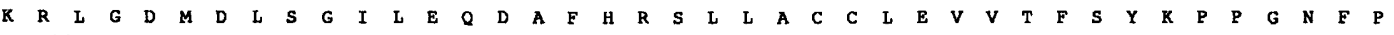

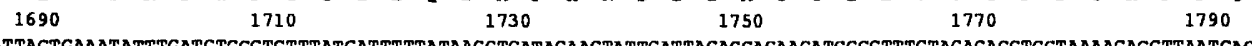

ATTTATTACTGAAATATTTGATGTGCCTCTTTATCATTTTTATAAGGTGATAGAAGTATTCATTAGAGCAGAAGATGGCCTTTGTAGAGAGGTGGTAAAACACCTTAATCAGATTGAAGA

$\begin{array}{llllllllllllllllllllllllllllllllllllllllll}E & I & T & E & I & F & D & V & P & L & Y & H & F & Y & K & V & I & E & V & F & I & R & A & E & D & G & L & C & R & E & V & V & K & H & L & N & Q & I & E & E\end{array}$

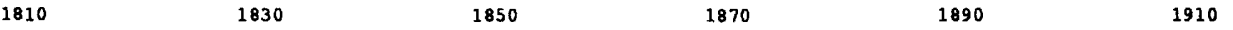

ACAGATCTTAGATCATTTGGCATGGAAACCAGAGTCTCCACTCTGGGAAAAAATTAGAGACAATGAAAACAGAGTTCCTACATGTGAAGAGGTCATGCCACCTCAGAACCTGGAAGGGC

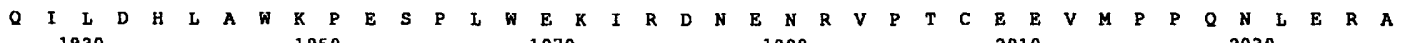

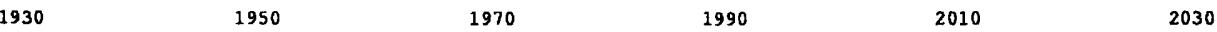

AGAT GAAATTTGCATTGCTGGCTCCCCTTTGACTCCCAGAAGGGTGACT GAAGTTCGT GCT GATACTGGAGGACTTGGAAGGAGCATAACATCTCCAACCACATTATACGATAGGTACAG

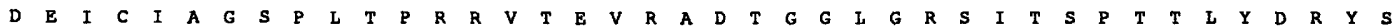

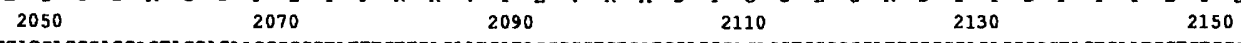

CTCCCCACCAGCCAGCACTACCAGAAGGCGGCTATTTGT TGAGAATGATAGCCCCTCTGATGGAGGGACACCTGGGCGGATGCCCCCACAGCCCCTAGTCAATGCTGTCCCTGTGCAGAA

$\begin{array}{llllllllllllllllllllllllllllllllllllllll}S & P & P & A & S & T & T & R & R & R & \text { L } & F & V & E & N & D & S & P & S & D & G & G & T & P & G & R & M & P & P & Q & P & \text { L } & V & N & A & V & P & V & Q & N\end{array}$ $217022190 \quad 2210 \quad 2230 \quad 2250 \quad 2270$

TGTATCTGGGGAGACTGTTTCTGTCACACCAGTTCCTGGACAGACTTTGGTCACCATGGCAACCGCCACTGTCACAGCCAACAATGGGCAAACGGTAACCATTCCTGTGCAAGGTATTGC

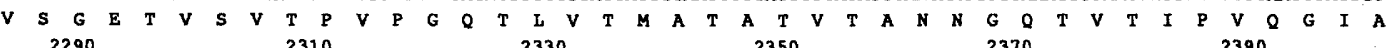

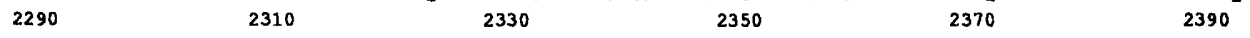

CAATGAAAATGGAGGGATAACATTCTTCCCTGTCCAAGTCAATGTTGGGGGGCAGGCACAAGCTGTGACAGGCTCCATCCAGCCCCTCAGTGCTCAGGCCCTGGCTGGAAGTCTGAGCTC

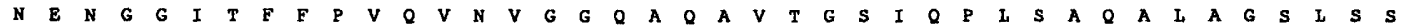

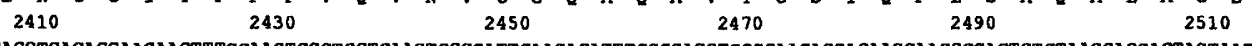

TCAACAGGTGACAGGAACAACTTTGCAAGTCCCTGGTCAAGTGGCCATTCAACAGATTTCCCCAGGTGGCCAACAGCAGAAGCAAGGCCAGTCTGTAACCAGCAGTAGTAATAGACCCAG

$\begin{array}{llllllllllllllllllllllllllllllllllllllll}Q & Q & V & T & G & T & T & L & Q & V & P & G & Q & V & A & I & Q & Q & \text { I } & S & P & G & G & Q & Q & Q & K & 0 & G & Q & S & V & T & S & S & S & N & R & P & R\end{array}$

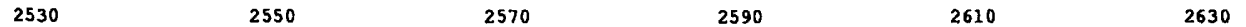

GAAGACCAGCTCTTTATCGCTTTTCTTTAGAAAGGTATACCATTTAGCAGCTGTCCGCCTTCGGGATCTCTGTGCCAAACTAGATATTTCAGATGAACTGAGGAAAAAAATCTGGACCTG

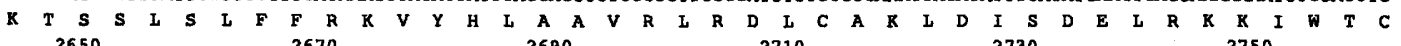
$2650202670 \quad 2690 \quad 2710 \quad 2730 \quad 2750$

CTTTGAATTCTCCATAATTCAGTGTCCTGAACTTATGATGGACAGACATCTGGACCAGTTATTAATGTGTGCCATTTATGTGATGGCAAAGGTCACAAAAGAAGATAAGTCCTTCCAGAA

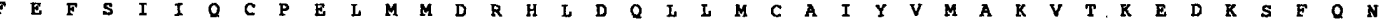

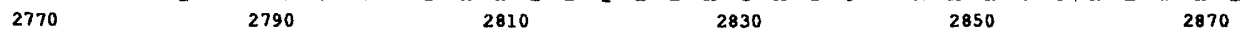

CATTATGCGTTGTTATAGGACTCAGCCGCAGGCCCGGAGCCAGGTGTATAGAAGTGTTTTGATAAAAGGGAAAAGAAAAAGAAGAAATTCTGGCAGCAGTGATAGCAGAAGCCATCAGAA

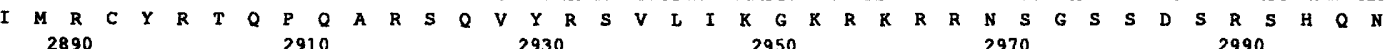
TTCTCCAACAGAACTAAACAAAGATAGAACCAGTAGAGACTCCAGTCCAGTTATGAGGTCAAGCAGCACCTTGCCAGTTCCACAGCCCAGCAGTGCTCCTCCCACACCTACTCGCCTCAC

$\begin{array}{lllllllllllllllllllllllllllllllllllllllll}S & P & T & E & L & N & K & D & R & T & S & R & D & S & S & P & V & M & R & S & S & S & T & L & P & V & P & Q & P & S & S & A & P & P & T & P & T & R & I & T\end{array}$ $3010303030 \quad 3050 \quad 3070 \quad 3090 \quad 3110$

AGGTGCCAACAGTGACATGGAAGAAGAGGAGAGGGGAGACCTCATTCAGTTCTACAACAACATCTACATCAAACAGATTAAGACATTTGCCATGAAGTACTCACAGGCAAATATGGATGC

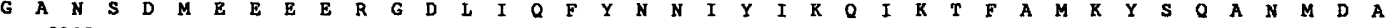

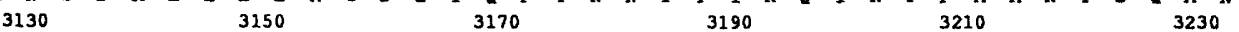

TCCTCCACTCTCTCCCTATCCATTTGTAAGAACAGGCTCCCCTCGCCGAATACAGTTGTCTCAAAATCATCCTGTCTACATTTCCCCACATAAAAATGAAACAATGCTTTCTCCTCGAGA

$\begin{array}{llllllllllllllllllllllllllllllllllllllll}P & P & I & S & P & Y & P & F & V & R & T & G & S & P & R & R & I & Q & L & S & Q & N & H & P & V & Y & I & S & P & H & K & N & E & T & M & L & S & P & R & E\end{array}$ $3250 \quad 3270 \quad 3290 \quad 3310 \quad 3330 \quad 3350$

AAAGATTTTCTATTACTTCAGCAACAGTCCTTCAAAGAGACTGAGAGAAATTAATAGTATGATACGCACAGGAGAAACTCCTACTAAAAAGAGAGGAATTCTTTTGGAGGATGGAGTGA

$\begin{array}{llllllllllllllllllllllllllllllllllllllll}K & I & F & Y & Y & F & S & N & S & P & S & K & R & L & R & E & I & N & S & M & I & R & T & G & E & T & P & T & K & K & R & G & I & L & \text { L } & E & D & G & S & E\end{array}$ 3370 3390 3410 3430

ATCACCTGCAAAAAGAATTTGCCCAGAAAATCATTCTGCCTTATTACGCCGTCTCCAAGATGTAGCTAATGACCGTGGTTCCCACTGA

$\begin{array}{lllllllllllllllllllllllllllll}S & P & A & R & R & I & C & P & E & N & H & S & A & L & L & R & R & L & Q & D & V & A & N & D & R & G & S & H & *\end{array}$

Figure 2 (See facing page for legend.) 
spacer that is not conserved either in length or in primary sequence. Spacer sequences are not required for viral oncoprotein binding, because their replacement by heterologous sequences does not affect such binding ( $\mathrm{Hu}$ et al. 1990; Ewen et al. 1991).

p $130^{\text {Rbr-2 }}$ shares substantial homology to the A and B subdomains of $\mathrm{Rb}$ and p107 (Fig. 3, boxes A and B), suggesting that $\mathrm{p} 130^{\mathrm{Rbr}-2}$ may also be capable of association with a number of proteins that are known to bind $\mathrm{Rb}$ and p107 through this domain (see below). Whereas no homology exists between the $\mathrm{Rb}$ and $\mathrm{p} 130^{\mathrm{Rbr}-2}$ spacer sequences, p107 and p130 ${ }^{\mathrm{Rbr}-2}$ are homologous in this region. Conservation of these spacer sequences may be functionally significant because the pl07 spacer can direct complex formation between p107 and cyclin A (Ewen et al. 1992; Faha et al. 1992). Finally, Rb, p130 ${ }^{\mathrm{Rbr}-2}$, and p107 share two additional regions of homology (Fig. 3, regions 1 and 2). Region 1 was identified previously in a comparison of $\mathrm{Rb}$ and pl07 sequences and was termed the amino-terminal homology region (Ewen et al. 1991). Although the function of these sequences is unknown, their conservation in all three family members suggests that these sequences may have some biological significance.

\section{p130 Rbr-2 binds to SV40 large $T$ antigen} and adenovirus E1A through the pocket domain

The amino acid sequence of $\mathrm{p} 130^{\mathrm{Rbr}-2}$ predicted that it contained a domain similar to that which is necessary for the binding of $\mathrm{Rb}$ and pl07 to ElA (termed the pocket). This domain also mediates binding to SV40 T antigen. To determine whether the $\mathrm{p} 130^{\mathrm{Rbr}-2}$ pocket domain could mediate such interactions, we tested the ability of $\mathrm{p} 130^{\mathrm{Rbr}-2}$ to bind $\mathrm{T}$ antigen and $\mathrm{E} 1 \mathrm{~A}$ in vitro. p130 ${ }^{\mathrm{Rbr}-2}$ (amino acids 58-1139; Fig. 2) was produced by in vitro translation and incubated with extracts prepared from human 293 cells or VAl3 cells. 293 cells express E1A; whereas VA13 cells express large $T$ antigen. We then asked whether antibodies directed against $\mathrm{T}$ antigen or ElA could coimmunoprecipitate ${ }^{35} \mathrm{~S}$-labeled p130 ${ }^{\text {Rbr-2 }}$. As shown in Figure 5, p130 Rbr-2 was specifically coimmunoprecipitated by an E1A antibody only when mixed with lysates from 293 cells; whereas antibodies directed against $T$-antigen coimmunoprecipitated $\mathrm{p} 130^{\mathrm{Rbr}-2}$ only after incubation of $\mathrm{p} 130^{\mathrm{Rbr}-2}$ with extracts from VA13 cells. These experiments suggested that p $130^{\mathrm{Rbr}-2}$ specifically bound to these viral proteins in vitro.

To confirm that this binding required a functional pocket domain, we took two approaches. A point mutation in the B subdomain of the Rb pocket changes cys- teine-706 to phenylalanine. This naturally occurring mutation, originally identified in the analysis of a smallcell lung carcinoma cell line, abrogates many of the growth suppressive effects of $\mathrm{Rb}$ and also abolishes the binding of $\mathrm{Rb}$ to viral oncoproteins (Kaye et al. 1990). Introduction of the same alteration at an analogous point in the p107 sequence (Cys-713) prevents association between p107 and T antigen or E1A (in addition to a number of cellular proteins; Ewen et al. 1992). Cys-894 of pl $30^{\mathrm{Rbr}-2}$ occupies a position within the $\mathrm{p} 130^{\mathrm{Rbr}-2}$ pocket subdomain B similar to that of Cys-706 in Rb. Consequently, we changed this cysteine residue to phenylalanine by site-directed mutagenesis and assayed the effect of this alteration on complex formation between p130 $0^{\mathrm{Rbr}-2}$ and $\mathrm{T}$ antigen or E1A. Neither viral protein bound detectably to the $\mathrm{p} 130^{\mathrm{Rbr}-2}$ pocket mutant, suggesting that binding did require an intact pocket domain (Fig. 5). To determine whether sequences in addition to the $\mathrm{p} 130^{\mathrm{Rbr}-2}$ pocket domain were required for viral oncoprotein binding, we constructed a fusion protein between glutathionine $S$-transferase (GST) and a portion of p130 ${ }^{\mathrm{Rbr}-2}$ consisting of only the A and B subdomains separated by the $\mathrm{p} 130^{\mathrm{Rbr}-2}$ spacer. Following production in bacteria, this fusion protein specifically bound to in vitro-translated $\mathrm{T}$ antigen (data not shown). These results suggest that the p130 Rbr-2 pocket domain is both necessary and sufficient for viral oncoprotein binding.

\section{p130 Rbr-2 binds to cyclins but not CDK2 in vitro}

Because the $p 130^{R b r-2}$ gene was isolated in a protein interaction screen in which CDK2 was the interaction target, it seemed possible that $\mathrm{p} 130^{\mathrm{Rbr}-2}$ and CDK2 might interact physically. Therefore, we tested the ability of Rbr-2 to bind to CDK2 both in vitro and upon coexpression in insect cells; however, we failed to detect any interaction between these two proteins. Although these experiments do not exclude the possibility that $\mathrm{p} 130^{\mathrm{Rbr}-2}$ and CDK2 might be capable of physical interaction in vivo, they suggested that during the interaction screen, p130 13 br-2 and CDK2 might have associated through their mutual binding to a third protein. CDK2 associates in vivo with several cyclins (A, E, D-type), and Rb and p107 can also bind to cyclins (see above). Therefore, members of this class of proteins seemed to be good candidates for forming a bridge between CDK2 and $\mathrm{p} 130^{\mathrm{Rbr}-2}$, and we tested the ability of $\mathrm{p} 130^{\mathrm{Rbr}-2}$ to interact with various cyclins in vitro.

We first tested the binding of $\mathrm{p} 130^{\mathrm{Rbr}-2}$ to cyclin proteins produced in bacteria. The complete open reading frames of cyclins A, D1, D2, D3, and E were fused to GST, and the resulting chimeric proteins were purified

Figure 3. Comparison of $\mathrm{p} 130^{\mathrm{Rbr}-2}$ with $\mathrm{Rb}$ and $\mathrm{p} 107$. A comparison of the amino acid sequence of $\mathrm{p} 130^{\mathrm{Rbr}-2}$ with $\mathrm{p} 107$ and $\mathrm{Rb}$ protein is shown. Regions of significant homology were identified using the BLAST program (Altschul et al. 1990). Vertical lines indicate identical amino acids. Regions corresponding to the A and B subdomains of the pocket domain are boxed and indicated as $A$ and $B$. In $\mathrm{Rb}$, the $\mathrm{A}$ and $\mathrm{B}$ subdomains have been shown to extend from amino acids $393 / 4$ to $571 / 2$ and $646 / 9$ to $772 / 3$, respectively (Hu et al. 1990; Huang et al. 1990; Kaelin et al. 1990). The area denoted 1 was identified previously as a region of homology between Rb and p107 and was termed the amino-terminal homology region. Area 2 was not noted in previous comparisons of Rb and pl07. 


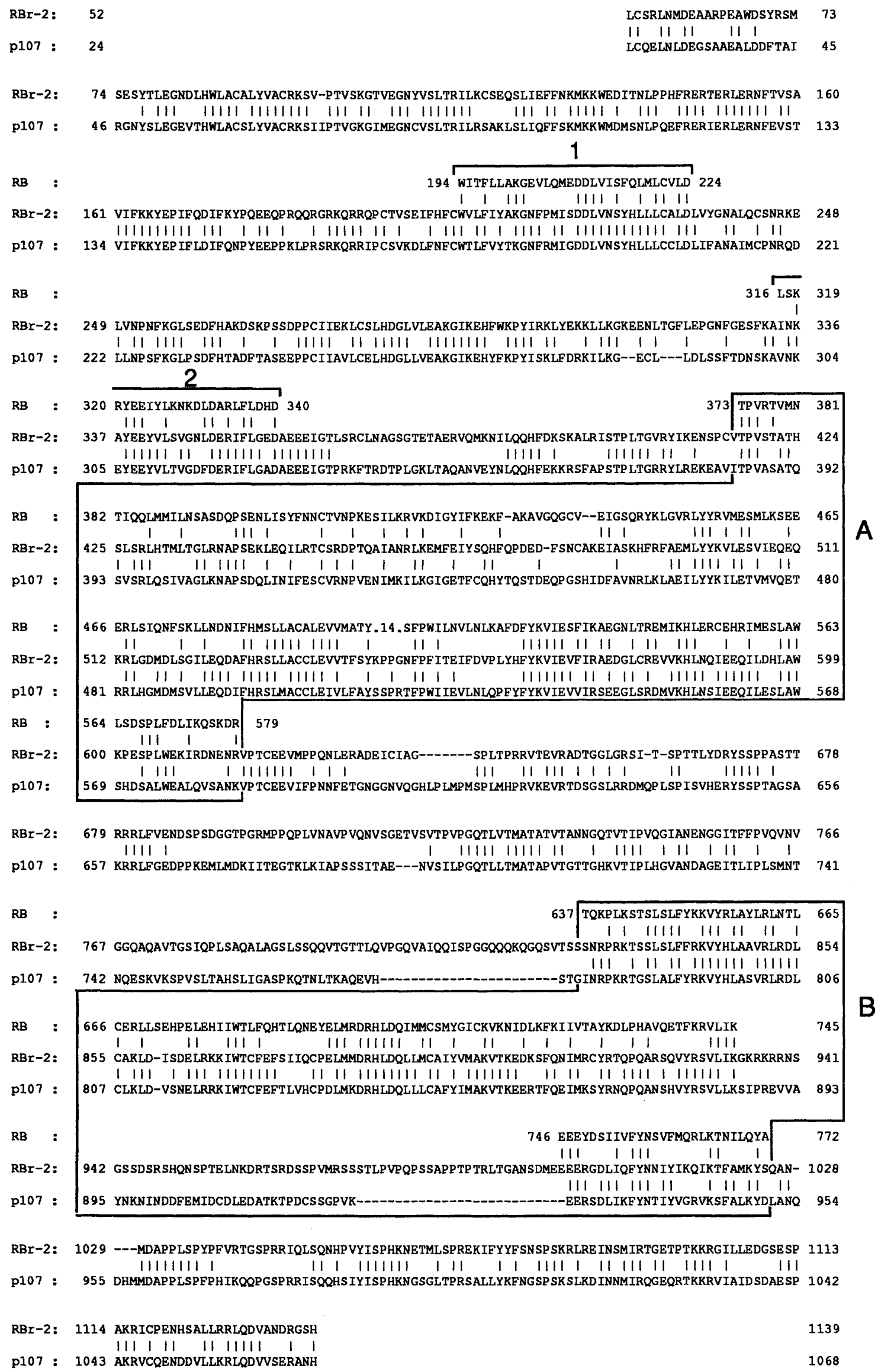

Figure 3. (See facing page for legend.) 


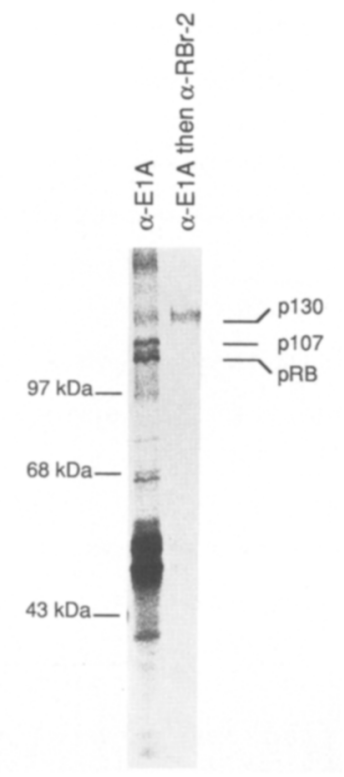

Figure 4. Rbr-2 is the adenovirus E1A-associated pl30. E1A and associated proteins were recovered from lysates of metabolically labeled 293 cells using a monoclonal ElA antibody (M73, lane $\alpha-E 1 A)$. Bound proteins were released and reimmunoprecipitated using a polyclonal antiserum specific for $\mathrm{Rbr}-2$ (lane $\alpha-E 1 A$ then $\alpha-R b r-2)$. The positions of pRb, pl07, and p130 are indicated. For reference, the positions of labeled protein markers, electrophoresed in parallel, are shown.

from overexpressing bacterial strains by affinity chromatography on glutathione-Sepharose. An equal amount $(0.5 \mu \mathrm{g})$ of each cyclin fusion protein was mixed with in vitro-translated $\mathrm{p} 130^{\mathrm{Rbr} \cdot 2}$ (carboxy-terminal 1082 amino acids); and following incubation, GST-cyclins were recovered by affinity chromatography on glutathioneSepharose. Despite stringent wash conditions $10.5 \mathrm{M}$ $\mathrm{NaCl}, 0.5 \% \mathrm{NP}-40$ ), a significant proportion of the $\mathrm{p} 130^{\mathrm{Rbr}-2}$ was recovered in association with each GSTcyclin fusion (Fig. 6A). In the case of GST-cyclin D2, $>10 \%$ of the $\mathrm{p} 130^{\mathrm{Rbr}-2}$ remained bound to the glutathione-Sepharose beads.

In parallel, we tested the ability of $\mathrm{p} 130^{\mathrm{Rbr}-2}$ to bind to CDK2 and cyclins in insect cells. We constructed a recombinant baculovirus that directed the expression of a fragment of $\mathrm{p} 130^{\mathrm{Rbr}-2}$ comprising its carboxy-terminal '1082 amino acids. This polypeptide contained, in addition, three tandem copies of the hemagglutinin (HA) epitope at its amino terminus (Field et al. 1988). Upon infection of insect cells (Sf9), this virus directed highlevel expression of the HA-tagged $\mathrm{p} 130^{\mathrm{Rbr}-2}$ (see Fig. 6B, lane -1 . Insect cells were then coinfected with viruses encoding $\mathrm{p} 130^{\mathrm{Rbr}-2}$ and either $\mathrm{CDK} 2$ or cyclin $\mathrm{A}, \mathrm{B} 1, \mathrm{D} 1$, D2, D3 (murine), or E under conditions where CDK or cyclin expression exceeded $\mathrm{p} 130^{\mathrm{Rbr}-2}$ expression. At 40 hr postinfection, infected cells were pulse-labeled for 4 $\mathrm{hr}$ with $\left[{ }^{35} \mathrm{~S}\right] \mathrm{methionine}$. Cells were then lysed, and $\mathrm{p} 130^{\mathrm{Rbr}-2}$ and associated proteins were recovered by immunoprecipitation with a monoclonal antibody directed against the HA epitope. The results of these experiments were essentially similar to those described above. Again, $\mathrm{p} 130^{\mathrm{Rbr}-2}$ bound several of the cyclins tested (see Fig. 6B). The best binding was to D cyclins; each of the D-type cyclins formed high stoichiometry complexes with $\mathrm{p} 130^{\mathrm{Rbr}-2}$ /the ratio in each case was calculated to be $\sim 1: 1$ based on quantitation of ${ }^{35} \mathrm{~S}$-labeled proteins but not taking into account potential differences in turnover rates). Cyclins $\mathrm{A}$ and $\mathrm{E}$ also bound $\mathrm{p} 130^{\mathrm{Rbr}-2}$ to a significant extent; when compared with D cyclins, approximately three- to five-fold less association was seen between $\mathrm{p} 130^{\mathrm{Rbr}-2}$ and cyclin A or E. Cyclin B1 bound $\mathrm{p} 130^{\mathrm{Rbr}-2}$ at only a very low level.

\section{Chromosomal location of the $\mathrm{p} 130^{\mathrm{Rbr}-2}$ gene}

The relationship of $\mathrm{p} 130^{\mathrm{Rbr}-2}$ to a known tumor suppressor prompted us to determine the chromosomal location of the gene encoding $\mathrm{p} 130^{\mathrm{Rbr}-2}$. A fragment of the $p 130^{R b r-2}$ genomic locus was isolated from a human placental genomic library and used as a probe for fluorescence in situ hybridization to human metaphase chromosomes (Fig. 7). The majority of the metaphases that we examined showed specific labeling of at least one pair of sister chromatids. In many metaphases, the sister chromatids of both homologous chromosomes were labeled. In all cases, signal was confined to a small, group E chromosome. DA-DAPI banding identified this as

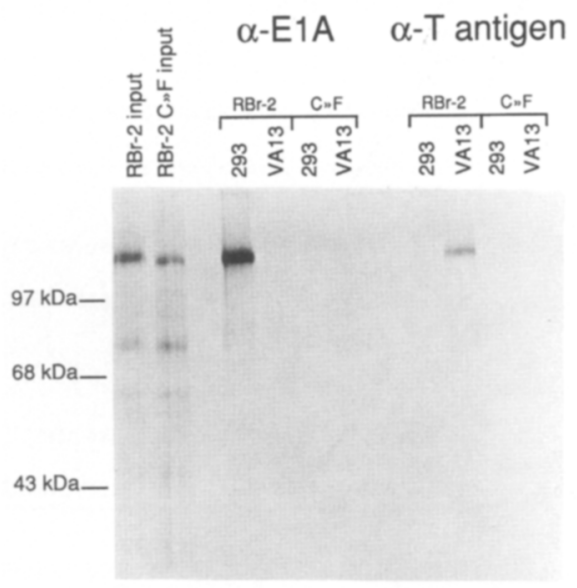

Figure 5. $\mathrm{p} 130^{\mathrm{Rbr}-2}$ binds adenovirus E1A and SV40 T-antigen. Lysates from either 293 cells (expressing E1A, as indicated) or VA13 cells (expressing $T$ antigen, as indicated) were mixed with $1 \mu l$ of an in vitro translation reaction that had been programmed with either wild-type $\mathrm{p} 130^{\mathrm{Rbr}-2}$ or a plasmid encoding a $\mathrm{pl} 30^{\mathrm{Rbr}-2}$ protein with a single amino acid substitution in the B subdomain of the pocket (Cys- $894 \rightarrow$ Phe, C $\gg F$, as indicated). Following immunoprecipitation with antibodies directed against either $\mathrm{T}$ antigen or E1A (as indicated), bound proteins were released by boiling in SDS sample buffer and analyzed by SDS-PAGE. Lanes marked Rbr- 2 input and Rbr- $2 \mathrm{C} \mathrm{C} \gg \mathrm{F}$ input show $10 \mu \mathrm{l}(1 / 50)$ of the initial binding reactions that were removed before immunoprecipitation. For reference, the positions of ${ }^{14} \mathrm{C}$-labeled protein markers (electrophoresed in parallel) are shown. 


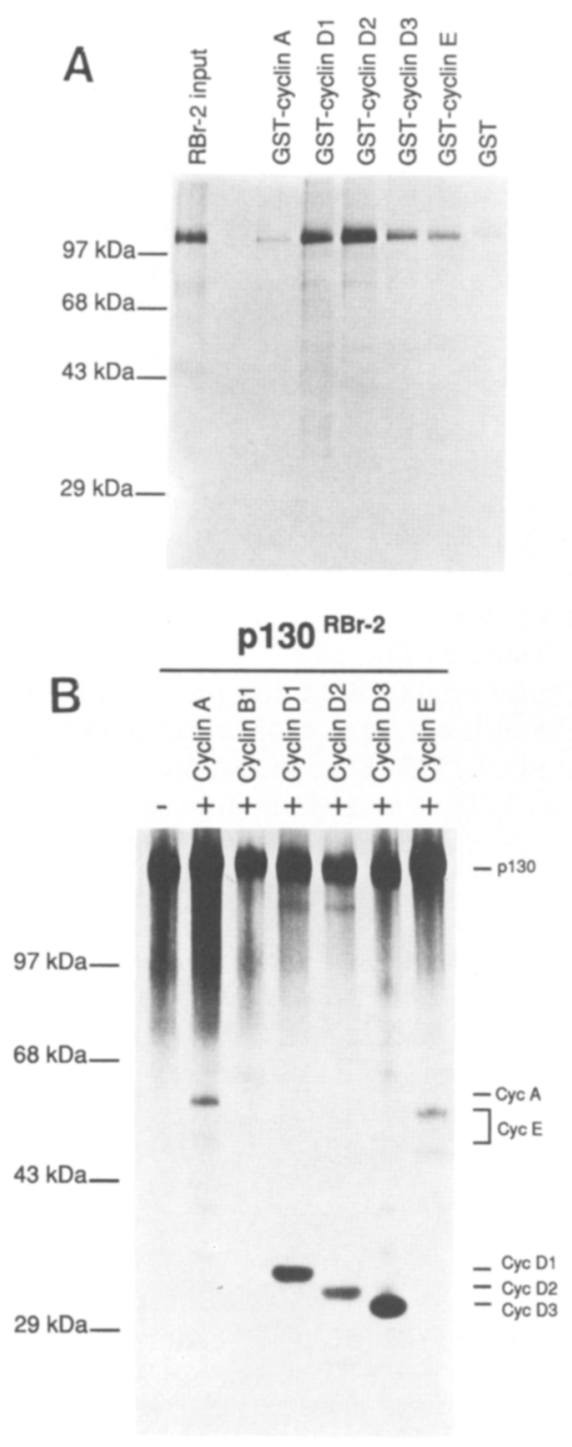

Figure 6. $\mathrm{p} 130^{\mathrm{Rbr}-2}$ can associate with cyclins in vitro. $(A) \mathrm{Bac}-$ terially produced fusions between GST and human cyclins A, D1, D2, D3, and E or GST alone (as indicated) were mixed with $1 \mu l$ of an in vitro translation reaction programmed with a plasmid encoding $\mathrm{p} 130^{\mathrm{Rbr}-2}$ (see Materials and methods). Following incubation, GST-cyclin fusion proteins were recovered on glutathione-Sepharose. Bound proteins were released by boiling in SDS sample buffer and analyzed by electrophoresis. The lane marked Rbr- 2 input shows $5 \mu l(1 / 40)$ of the binding reaction that was removed before the addition of Sepharose beads. $(B)$ Insect ( $\mathrm{Sf}$ ) cells were infected with a baculovirus directing the expression of an eptitope-tagged fragment of the $\mathrm{p} 130^{\mathrm{Rbr}-2}$ protein (see text) or this virus in combination with viruses encoding cyclin A, B1, D1, D2, D3, or E (as indicated). At $40 \mathrm{hr}$ postinfection, cells were pulse-labeled with $\left[{ }^{35} \mathrm{~S}\right]$ methionine. p130 $\mathrm{Rbr}-2$ and associated proteins were recovered from cell lysates by immunoprecipitation (see Materials and methods) with a monoclonal antibody directed against the epitope tag. Bound proteins were analyzed by SDS-PAGE. The positions of $\mathrm{p} 130^{\mathrm{Rbr}-2}$ and of each cyclin are indicated. For reference, the locations of ${ }^{14} \mathrm{C}$ labeled protein markers (electrophoresed in parallel) are shown for each panel. chromosome 16, and analysis of high-resolution chromosome spreads placed the map position at 16q13 (Fig. 7). Two other independent genomic clones of $\mathrm{p} 130^{\mathrm{Rbr}-2}$ also mapped to this position (data not shown).

Localization of $p 130^{R b r-2}$ to chromosome 16 was confirmed independently using a series of hamster-human somatic cell hybrids. Each cell line harbors a defined subset of human chromosomes (see Materials and meth-

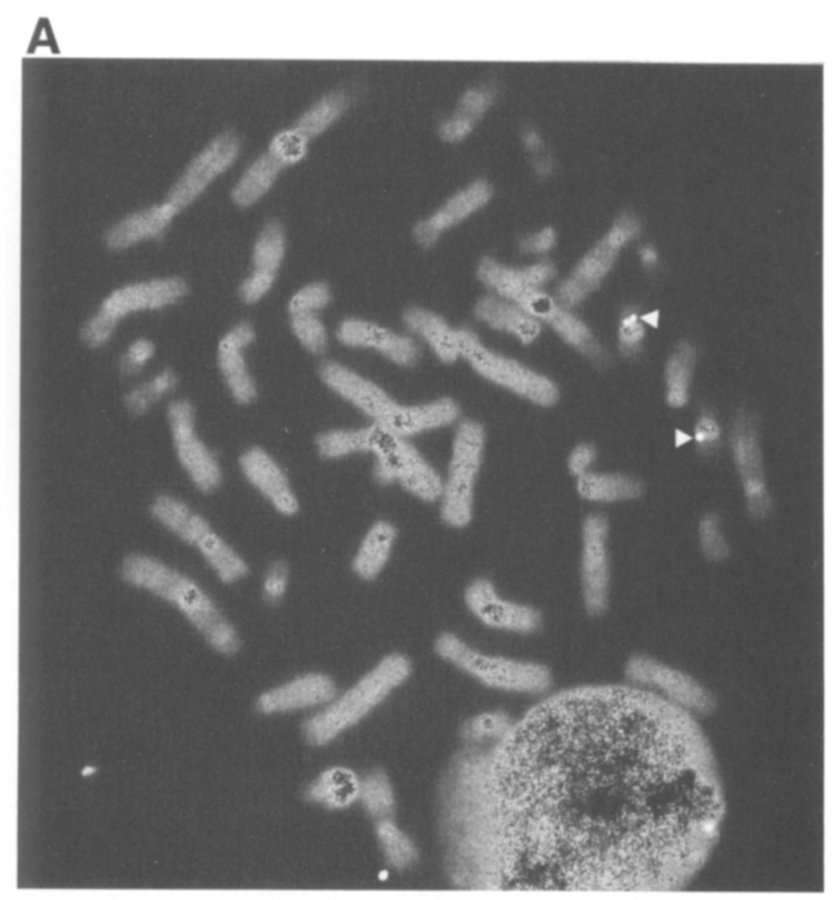

B

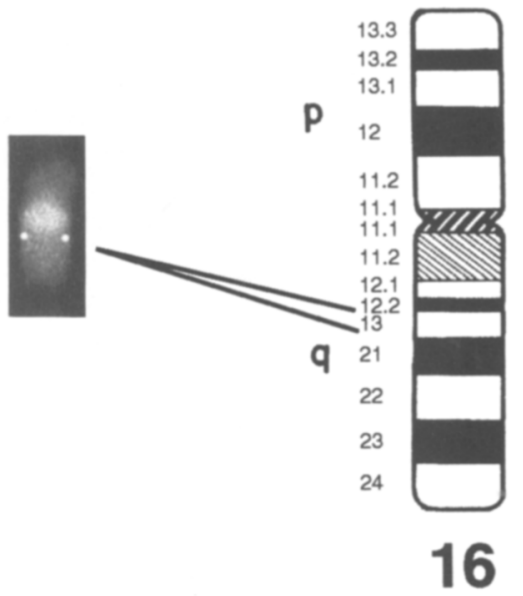

Figure 7. (A) Dual chromatid Cy3 fluorescence (arrowheads) on chromosome 16 corresponding to specific hybridization of the digoxygenin-labeled genomic $\mathrm{p} 130^{\mathrm{Rbr}-2}$ probe. $(B) \mathrm{A}$ higher resolution preparation of chromosome 16 , demonstrating the localization of the $\mathrm{p} 130^{\mathrm{Rbr}-2}$ gene to the q13 region (white dots). Chromosomes are counterstained with DAPI/actinomycin. Kodachrome images were digitized and converted to gray scale. Red Cy3 fluorescence was pseudocolored to white. 
ods). PCR analysis of genomic DNA from 25 such cell lines gave a pattern of amplification consistent only with the $p 130^{R b r-2}$ gene residing on chromosome 16 /data not shown).

\section{Discussion}

We have used a two-hybrid protein interaction screen to identify cDNAs that encode proteins capable of physically associating with the cell cycle regulatory kinase CDK2. Three such proteins were identified: cks1, a previously isolated human homolog of fission yeast suc1; KAP, a dual specificity protein phosphatase; and p130 ${ }^{\text {Rbr-2 }}$, a new member of the Rb family. p130 shares $\sim 50 \%$ amino acid identity with another Rb-related protein, p107, over the entire length of p107. In addition, $\mathrm{Rb}$ and $\mathrm{pl} 30^{\mathrm{Rbr}-2}$ share considerable homology in their pocket domains. pl30 13 br-2, p107, and $\mathrm{Rb}$ all share two additional regions of significant identity near their amino termini (Fig. 3, 1 and 2); and although the function of these sequences remains unknown, their potential importance is suggested by their conservation in all three family members.

$\mathrm{p} 130^{\mathrm{Rbr}-2}, \mathrm{Rb}$, and p107 not only share primary sequence homology but also functional similarity. Each of these proteins can bind specifically to the viral oncoproteins, SV40 $\mathrm{T}$ antigen and adenovirus E1A. The alteration of a conserved cysteine residue within the pocket domain of any of these three proteins destroys its ability to bind to either $\mathrm{T}$ antigen or E1A . A number of cellular proteins associate with $\mathrm{Rb}$ and p107 through their pocket domains (Kaelin et al. 1991; Ewen et al. 1992), and it will be important to determine whether $\mathrm{p} 130^{\mathrm{Rbr}-2}$ binds a similar set of proteins in this manner.

The structural and functional similarities between $\mathrm{Rb}$ and $\mathrm{p} 130^{\mathrm{Rbr}-2}$ raise the question of whether $\mathrm{p} 130^{\mathrm{Rbr}-2}$ might act as an inhibitor of cellular proliferation or as a tumor suppressor gene. To gain insight into this question, we have mapped the chromosomal location of the $\mathrm{p} 130^{\mathrm{Rbr}-2}$ gene. $\mathrm{pl} 30^{\mathrm{Rbr}-2}$ resides on the short arm of chromosome 16 at the locus 16q13. Interestingly, several studies have identified a putative Wilms' tumor gene (WT3) localized to $16 \mathrm{q}$; one group proposed that up to $20 \%$ of Wilms' tumor patients have a deletion in the area of 16q13-16q22 (Maw et al. 1992; Slater and Mannens 1992). Karyotypic analyses have also identified deletions of $16 \mathrm{q}$ as a significant abnormality in Wilms' tumors (Kaneko et al. 1991). In addition, loss of heterozygosity (LOH) at 16q has been detected in a variety of other solid tumors. Several studies of breast carcinomas have found alterations of 16q (Mitchell and Santibanez-Koref 1990; Sato et al. 1990, 1991). Up to $45 \%$ of primary breast carcinomas show LOH of $16 \mathrm{q}$ markers. $\mathrm{LOH}$ of $16 \mathrm{q}$ and $10 \mathrm{q}$ markers has also been found in up to $30 \%$ of prostatic adenocarcinomas (Carter et al. 1990; Isaacs and Carter 1991). Finally, hepatocellular carcinomas (Zhang et al. 1990; Yokata et al. 1991) and primitive neuroectodermal tumors (Thomas and Raffel 1991) show LOH of the $16 \mathrm{q}$ region. On the basis of these studies, it seems likely that a tumor suppressor gene is localized to $16 \mathrm{q}$ (although in several cases its location has been proposed to be 16q22-16q24, distal to that of the p130 13 rr-2 genel, and the intriguing possibility that $\mathrm{p} 130^{\mathrm{Rbr}-2}$ may act as a tumor suppressor remains to be explored.

$\mathrm{p} 130^{\mathrm{Rbr}-2}$ was isolated in a protein interaction screen in which CDK2 was the interaction target, but $\mathrm{p} 130^{\mathrm{Rbr}-2}$ failed to bind directly to CDK2 in vitro under a variety of conditions. Instead, $\mathrm{p} 130^{\mathrm{Rbr}-2}$ bound to a number of different cyclins. That CDK2 is also known to interact with cyclins raises the possibility that $\mathrm{p} 130^{\mathrm{Rbr}-2}$ and CDK2 interacted in a yeast cell through their mutual binding to an S. cerevisiae cyclin (Fig. 8). On the basis of this model, we suggest that two proteins may not need to interact directly for their association to be detected in a twohybrid screen. This possibility is interesting in light of the fact that $\mathrm{p} 130^{\mathrm{Rbr}-2}$ interacted in yeast with CDK2 but not with cdc2. As in $S$. pombe, control of the $\mathrm{G}_{1} / \mathrm{S}$ and $\mathrm{G}_{2} / \mathrm{M}$ transitions in $S$. cerevisiae is accomplished by the action of a single CDK, p34 ${ }^{\mathrm{CDC} 28}$ (for review, see Draetta 1990). Conditional CDC28 mutants can be fully complemented by either human cdc2 or human CDK2 (Wittenberg and Reed 1989; Elledge and Spottswood 1991), implying that both of these human proteins can bind all of the yeast cyclins that are essential for cell cycle progression. If $\mathrm{p} 130^{\mathrm{Rbr}-2}$ and CDK2 interact in yeast via an $S$. cerevisiae cyclin (cyclin $X_{;}$Fig. 8), our data suggest that this cyclin binds to CDK2 but not to cdc2. Candidates for such a cyclin can be found among the $S$. cerevisiae $G_{1}$ cyclins (CLN1, CLN2, and CLN3) or the recently isolated CLB cyclins (Richardson et al. 1989,1992; Lew et al. 1991; Fitch et al. 1992). None of these proteins is individually essential for viability, and this allows for the possibility that one of them might preferentially interact with human CDK2. An alternate possibility is that elements present both in CDK2 and in a yeast cyclin contributed to the $\mathrm{p} 130^{\mathrm{Rbr}-2}-\mathrm{CDK} 2$ interaction.

We have found that $\mathrm{p} 130^{\mathrm{Rbr}-2}$ can interact with several different cyclins in vitro. Similar binding specificities are seen using cyclins produced as fusion proteins in bacteria and cyclins produced in baculovirus-infected insect cells. p130 has been shown to interact with cyclins A and $\mathrm{E}$ in vivo (Faha et al. 1993; see Li et al., this issue), and we have found that similar interactions occur in vitro (see Fig. 6). It was initially surprising that such interactions were relatively inefficient; however, Peeper

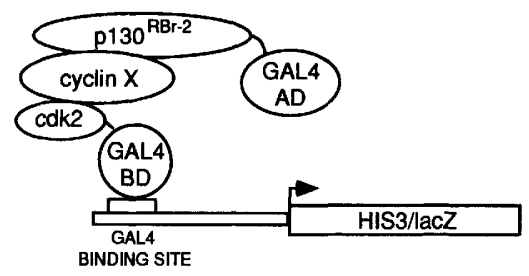

Figure 8. Model for the interaction of the Gal4 DNA-binding domain-CDK2 fusion with the Gal4 activation domain$\mathrm{p} 130^{\mathrm{Rbr}-2}$ fusion during the two-hybrid screen. A schematic representation of the interaction of $\mathrm{p} 130^{\mathrm{Rbr}-2}$ and CDK2 through mutual binding to a $S$. cerevisiae cyclin (cyclin $\mathrm{X}$ ) is shown. 
$\mathrm{p} 130^{\mathrm{Rbr}-2}$, a new member of the $\mathrm{Rb}$ gene family

et al. (1993) have recently demonstrated that cyclin A binds to p107 only when complexed with CDK2. Cyclins $\mathrm{A}$ and $\mathrm{E}$ are likely to bind $\mathrm{p} 130^{\mathrm{Rbr}-2}$ in a similar manner based on the homology between the $\mathrm{p} 130^{\mathrm{Rbr}-2}$ and $\mathrm{p} 107$ spacer elements. Therefore, binding of cyclins $\mathrm{A}$ and $\mathrm{E}$ was probably limited in our in vitro experiments by the availability of CDK2 in either reticulocyte lysates (Fig. 6A) or baculovirus-infected insect cells (Fig. 6B). $\mathrm{p} 130^{\mathrm{Rbr}-2}$ also bound strongly to all three of the D-type cyclins (Fig. 6) and could serve as a substrate for cyclin $\mathrm{D} / \mathrm{CDK} 4$ kinase complexes formed in baculovirus-infected insect cells (data not shown). In this regard, the properties of $\mathrm{p} 130^{\mathrm{Rbr}-2}$ are similar to those described for $\mathrm{Rb}$ and $\mathrm{p} 107$. $\mathrm{Rb}$ has been reported to interact with cyclins D1 and D3 (Dowdy et al. 1993) or D2 and D3 (Ewen et al. 1993), and p107 has been shown to bind D2 and D3. In addition, both p107 and $\mathrm{Rb}$ can be phosphorylated by insect cell lysates containing cyclin D/CDK4 kinase complexes. These findings suggested that one function of cyclin D/CDK4 complexes might be to phosphorylate $\mathrm{Rb}$ and abrogate its growth-suppressive effects. In a number of cases, the expression of D-type cyclins is altered upon growth factor stimulation (Matsushime et al. 1991; Cocks et al. 1992; Inaba et al. 1992; Won et al. 1992); therefore, the ability of cyclin D kinase complexes to phosphorylate $\mathrm{Rb}$ might provide a link between growth control and cell cycle control. $\mathrm{p} 130^{\mathrm{Rbr}-2}$ can also interact, at least in vitro, with D-type cyclins, suggesting that $\mathrm{p} 130^{\mathrm{Rbr}-2}$ functions might be subject to similar regulation.

Both $\mathrm{Rb}$ and pl07 are capable of forming complexes with a transcription factor, E2F, that has been implicated in the control of a number of genes with expression critical for cell growth. These include c-fos, c-myc, and DHFR (for review, see Wagner and Green 1991). Complexes between $\mathrm{E} 2 \mathrm{~F}$ and $\mathrm{Rb}$ can actively silence transcription when bound to E2F sites (Weintraub et al. 1992); however, it is thought that upon phosphorylation of $\mathrm{Rb}, \mathrm{Rb}-\mathrm{E} 2 \mathrm{~F}$ complexes dissociate and E2F can then act to stimulate transcription (Chellapan et al. 1991; e.g., see Hiebert et al. 1992). Complexes between E2F and p107 have been less well characterized. For example, it is not known whether these complexes normally recognize a subset of E2F sites that overlaps those recognized by $\mathrm{Rb}$ E2F complexes in vivo. During $\mathrm{G}_{1}, \mathrm{E} 2 \mathrm{~F}$ and p107 are present in a multicomponent complex that also contains cyclin $\mathrm{E}$ and $\mathrm{CDK} 2$. During $\mathrm{S}$ phase, cyclin $\mathrm{A}$ takes the place of cyclin E in a similar complex (Mudryj et al. 1991; Devoto et al. 1992; Lees et al. 1992). pl30 Rbr-2 also associates with an E2F-related protein (Cobrinik et al., this issue). In this regard, it is possible that each member of the growing family of pocket proteins might regulate different sets of genes through its interaction with individual members of a family of E2F-like transcription factors. Alternatively, each member of the $\mathrm{Rb}$ family of proteins may regulate a similar or overlapping set of genes either in response to different cellular signals or at different phases of the cell cycle.

The differences between the roles of $\mathrm{Rb}$ and $\mathrm{p} 107$ and the putative role of $\mathrm{p} 130^{\mathrm{Rbr}-2}$ in linking cell cycle control to various aspects of growth control remain to be elucidated. However, an intriguing possibility is provided by the recent demonstration that $\mathrm{Rb}$ can play a role in controlling the differentiation of muscle cells in culture $\mid \mathrm{Gu}$ et al. 1993). In this system, Rb influences the developmental decisions made by these cells through its interaction with myoD. MyoD is a transcription factor that regulates the expression of a number of muscle specific genes and with its inappropriate expression can induce the myogenic pathway in a variety of cell lineages (e.g., see Weintraub et al. 1991). The interaction between $\mathrm{Rb}$ and a regulator of differentiation suggests a mechanism by which the $\mathrm{Rb}$ family of proteins may serve to couple developmental decisions to cell cycle control. For example, each member of the $\mathrm{Rb}$ family might interact with a different subset of transcription factors that regulate the expression of the differentiated phenotype in specific cell lineages.

The isolation of $\mathrm{p} 130^{\mathrm{Rbr}-2}$ in a screen designed to reveal proteins that can interact with $\mathrm{CDK} 2$ underscores the intimate relationship between the $\mathrm{Rb}$ family of proteins and the regulation of the cell cycle. An elucidation of the specific role of each member of the $\mathrm{Rb}$ family in cell cycle regulation is likely to shed light on the mechanisms by which cell cycle control is linked to proliferative or developmental decisions.

\section{Materials and methods \\ Construction of cDNA libraries}

Fifteen micrograms of poly $(\mathrm{A})^{+}$RNA isolated from HeLa S3 suspension cells was used as a substrate for cDNA synthesis using the Unizap XR cloning kit (Stratagene) according to the manufacturer's instructions. Resulting double-stranded cDNA with EcoRI and $X h o I$ ends had an average size of $\sim 1.5 \mathrm{~kb}$. This cDNA (375 ng) was ligated to $600 \mathrm{ng}$ of EcoRI/Xhol-digested pGAD-GH (see below) for 2 days at $16^{\circ} \mathrm{C}$. Following ligation, the library was phenol/chloroform extracted, precipitated with ethanol, and electrotransformed into Escherichia coli DH10B (BioRad). The library contained $\sim 7 \times 10^{6}$ primary recombinants. Library DNA was obtained by plating primary transformants on one hundred 150-mm LB-AMP plates. Colonies were scraped into LB media, and DNA was prepared by standard methods. pGAD-GH is a derivative of pGAD10 /generously supplied by $P$. Bartel and S. Fields, SUNY, Stony Brook, NY). It differs from pGAD10 essentially in that it contains a complete ADH promoter and a portion of the pBluescript (Stratagene) polylinker.

Two-hybrid screens

For two-hybrid screening, the complete open reading frame of human CDK2 was inserted into the vector pGBT9/P. Bartel and $\mathrm{S}$. Fields, unpubl.). This vector directs the expression of a fusion between the DNA-binding domain (amino acids 1-147) of Gal4 and the entire CDK2 protein from a crippled ADH promoter. This plasmid, which also contains a TRP1 marker, was cotransformed with the HeLa cell cDNA library (LEU2 marker) into the yeast strain YPB2 (a, ura3-52, his3-200, ade2-101, lys2-801, trp1-901, leu2-3, CAN ${ }^{\mathrm{r}}$ gal4-542, gal80-538, LYS2::gal1 uas $^{-}$

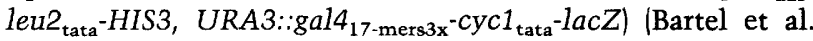
1993). Transformants were plated on yeast drop-out media lacking leucine, tryptophan, and histidine and containing $30 \mathrm{~mm}$ 
3-amino-1,2,4,triazole (3-AT). Our best estimates indicate that $\sim 1 \times 10^{6}$ transformants were analyzed; precise determination of the number of primary transformants is complicated by the fact that plating efficiency is much lower on plates containing 3-AT than on plates that select only for the presence of the target and library plasmids. After 10-14 days of growth, $\mathrm{HIS}^{+}$colonies were scored for $\beta$-galactosidase activity as follows: Colonies (or patches derived from the original positive colonies) were lifted from plates directly onto Whatman 50 filters, quick frozen in liquid nitrogen $(\sim 10 \mathrm{sec})$, and immediately overlaid onto Whatman $3 \mathrm{MM}$ filters that had been soaked in $\beta$-galactosidase assay buffer $\left(60 \mathrm{mM} \mathrm{Na}{ }_{2} \mathrm{HPO}_{4} \cdot 7 \mathrm{H}_{2} \mathrm{O}, 60 \mathrm{mM} \mathrm{NaH} \mathrm{PO}_{4} \cdot 7 \mathrm{H}_{2} \mathrm{O}, 10 \mathrm{~mm}\right.$ $\mathrm{KCl}, 1 \mathrm{~mm} \mathrm{MgSO}{ }_{4} \cdot 7 \mathrm{H}_{2} \mathrm{O}, 50 \mathrm{~mm} \beta$-mercaptoethanol, $0.01 \%$ $\mathrm{X}$-gal). Filter sandwiches were placed in petri dishes and incubated at $30^{\circ} \mathrm{C}$. Positive colonies showed blue color in from 30 $\mathrm{min}$ to several hours. These colonies were picked directly from the assay filters and restruck on selective media. Plasmid DNA was recovered from positive colonies and introduced by electroporation into E. coli MH4 (see Bartel et al. 1993). $\mathrm{MH}_{4}$ is leuB ${ }^{-}$, and this defect can be complemented by the LEU2 gene on the library plasmid. Thus, on minimal media only transformants carrying the library plasmid, and not those carrying the target plasmid, will grow.

Primary positives were tested for target specificity by retransformation into the test strain (YPB2) in conjunction with a number of different Gal4 DNA-binding domain-target fusions (fusions with CDK2, cdc2, CDK5, SNF1, piml; the SNF1 fusion was a gift from $S$. Fields, the CDK5 fusion was kindly provided by $\mathrm{H}$. Zhang (this laboratory), and the piml fusion was a gift from $\mathrm{H}$. Feilotter, this laboratory). Only library plasmids that did not activate marker expression in the presence of SNF1 or pim 1 were analyzed further. The library plasmid encoding the human suc1 homolog was isolated using a different tester strain, YGHl (a, ura3-52, his3-200, ade2-101, lys2-801, trp1-

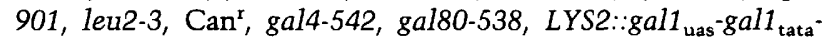
HIS3, URA3::gal1-lacZ). This screen was performed identically to that described above except that 3-AT was not included in the selective media.

\section{Analysis of cDNAs encoding $p 130^{\text {Rbr-2 }}$}

For sequence analysis, cDNAs were excised from pGAD-GH and inserted into pBluescript SK(-) and pBluescript $\mathrm{KS}(-)$ ) (Stratagene). Unidirectional deletions were prepared from both of these plasmids using the double-stranded nested deletion kit (Pharmacia). The complete sequence of both strands of the p130 ${ }^{\mathrm{Rbr}-2}$ cDNA was determined by sequencing overlapping deletions on an ABI 373A automated sequencer. The full-length p130 cDNA was obtained by PCR from the HeLa cell cDNA library. Three successive rounds of amplification were performed using nested primers. In each case, one primer was derived from the Gal4 activation domain sequence and one primer was derived from the Rbr-2 sequence present in our original clone. After three rounds of amplification, the largest products were isolated, subcloned, and sequenced. To avoid error, fragments derived from three independent PCR reactions were analyzed.

\section{Production of p130 antibodies}

and reimmunoprecipitation experiments

A plasmid encoding a fusion between GST and amino acids $757-828$ of $\mathrm{p} 130^{\mathrm{Rbr}-2}$ was introduced into E. coli BL21. Fusion proteins were expressed and purified as described below. Polyclonal antisera to this fusion protein were generated by Pocono Rabbit Farm and Laboratory.
For reimmunoprecipitation experiments, human 293 cells were metabolically labeled with $\left[{ }^{35} \mathrm{~S}\right]$ methionine, and lysates were prepared as described (Xiong et al. 1993). ElA and associated proteins were recovered by immunoprecipitation with a monoclonal E1A antibody, M73. Proteins were released from the immunoprecipitate by boiling in $0.25 \times$ Laemmli sample buffer. Protein A-Sepharose was removed by centrifugation, and the supernatant $(40 \mu \mathrm{l})$ was diluted to $1 \mathrm{ml}$ in $50 \mathrm{~mm}$ Tris (pH 8.0), $150 \mathrm{mM} \mathrm{NaCl}$, and $0.5 \%$ NP-40. Reimmunoprecipitation of p130 was carried out using $1 \mu \mathrm{l}$ of the $\alpha$-Rbr- 2 polyclonal antisera.

\section{In vitro binding experiments}

For use in in vitro binding experiments the $\mathrm{p} 130^{\mathrm{Rbr}-2}$-coding region was inserted into the translational enhancing vector pCITE (Novogen). The $\mathrm{p} 130^{\mathrm{Rbr}-2} \mathrm{C}_{894} \mathrm{~F}$ mutation was created by in vitro mutagenesis of the $\mathrm{p} 130^{\mathrm{Rbr}-2} \mathrm{cDNA}$ in pBluescript SK $\mid-$ | as described (Hannon et al. 1990). An 835-bp SacI-XhoI fragment from the mutant gene was then used to replace the identical fragment in pCITE-pl30 $0^{\mathrm{Rbr}-2}$. For all experiments, in vitro-translated proteins were synthesized using a coupled transcription-translation system (TNT lysate, Promega).

For $\mathrm{T}$ antigen- and ElA-binding experiments, $1 \mu \mathrm{l}$ of an in vitro translation reaction was mixed with $125 \mu \mathrm{g}$ of lysate from either 293 or VA13 cells. The preparation of the cellular extracts and assay for binding was performed exactly as described (Kaelin et al. 1990).

For use in cyclin-binding experiments, the entire coding sequence of cyclins A, D1, D2, D3, and E were inserted into the expression vector pGEX-KG (Guan and Dixon 1991), which directs the synthesis of GST fusion proteins (pGEX-cyclins A, D1, $D 2$, and D3 were gifts from Y. Xiong, this laboratoryl. For the preparation of fusion proteins, GST-cyclin expression vectors were transformed into $E$. coli BL21. Transformants were grown to an $\mathrm{OD}_{600}$ of 0.5 and were then induced to express fusion protein by the addition of IPTG to $0.4 \mathrm{~mm}$. Induction was allowed to proceed for $10-12 \mathrm{hr}$ at $23-25^{\circ} \mathrm{C}$, after which time the cells were washed once in PBS and then resuspended in $10 \mathrm{ml}$ of GST column buffer [GCB: $50 \mathrm{~mm}$ Tris at pH 8.0, $200 \mathrm{~mm} \mathrm{NaCl}$, $1 \mathrm{~mm}$ EDTA, $1 \%$ Triton X-100, $1 \mathrm{~mm}$ DTT, $1 \times$ protease inhibitors $(2 \mu \mathrm{g} / \mathrm{ml}$ of leupeptin, $2 \mu \mathrm{g} / \mathrm{ml}$ of aprotinin, $0.3 \mu \mathrm{g} / \mathrm{ml}$ of benzamide, $10 \mu \mathrm{g} / \mathrm{ml}$ of soybean trypsin inhibitor, $100 \mu \mathrm{g} / \mathrm{ml}$ of TPCK, $50 \mu \mathrm{g} / \mathrm{ml}$ of TLCK)]. Cells were lysed by five sequential 30 -sec of sonications on ice, and lysates were cleared by centrifugation (10 min at $9600 \mathrm{~g}$ ). Fusion proteins were recovered by affinity chromatography on glutathione-Sepharose (Pharmacia). Chromatography was essentially as described by the manufacturer except that it was carried out in $\mathrm{GCB}$ and a $0.7-\mathrm{M} \mathrm{NaCl}$ wash was performed before elution.

For in vitro cyclin binding, $1 \mu \mathrm{l}$ of an $\mathrm{p} 130^{\mathrm{Rbr}-2}$ in vitro translation reaction was mixed with $0.5 \mu \mathrm{g}$ of each GST-cyclin fusion protein or $3 \mu \mathrm{g}$ of GST alone in $200 \mu \mathrm{l}$ of GST binding buffer (GBB: $50 \mathrm{~mm}$ Tris at $\mathrm{pH} 8.0,120 \mathrm{~mm} \mathrm{NaCl}, 1 \mathrm{~mm}$ DTT, $0.5 \% \mathrm{NP}-40,1 \times$ protease inhibitors) and incubated for $1 \mathrm{hr}$ at $4^{\circ} \mathrm{C} .15 \mu \mathrm{l}$ of glutathione-Sepharose (prewashed with GBB) was then added, and the binding reactions were then rotated for an additional $30 \mathrm{~min}$ at $4^{\circ} \mathrm{C}$. The glutathione-Sepharose was then washed five times in GBB containing $0.5 \mathrm{M} \mathrm{NaCl}$. Bound proteins were released by boiling in SDS sample buffer and electrophoresed on a $10 \%$ SDS-PAGE gel. Quantitation of the binding reactions was carried out on a FUII BAS2000 bio-imager.

Interaction of $p 130^{R b r-2}$ and cyclins in baculovirusinfected insect cells

A baculovirus that directs the expression of a fusion between 
$\mathrm{p} 130^{\mathrm{Rbr}-2}$, a new member of the $\mathrm{Rb}$ gene family

the HA epitope (Field et al. 1988) and the carboxy-terminal 1082 amino acids of $\mathrm{p} 130^{\mathrm{Rbr}-2}$ was constructed using the Pharmingen Baculo-gold kit. This was used to infect insect (Sf9) cells either alone or in combination with viruses directing the expression of CDK2 or human cyclins A, E, D1 or D2, or murine cyclin D3. Viruses encoding cyclins D1 and D2 were supplied by Dr. Stephen Gruenwald (Pharmingen, Palo Alto, CA) and viruses encoding CDK2, cyclin A, cyclin E, and murine cyclin D3 were a gift of Dr. Charles Sherr (St. Jude, Memphis, TN). For each experiment $4 \times 10^{5} \mathrm{Sf} 9$ cells were seeded in each well of a 12 well tissue culture plate. $\mathrm{p} 130^{\mathrm{Rbr}-2}$ virus was used at an m.o.i. of $\sim 5$; CDK2 and cyclin viruses were used at an m.o.i. of $\sim 15$. At $40 \mathrm{hr}$ postinfection, cells were pulse-labeled with $0.1 \mathrm{mCi}$ of $\left[{ }^{35} \mathrm{~S}\right]$ methionine (Express label, NEN). After $4 \mathrm{hr}$ of labeling, cells were lysed in $500 \mu \mathrm{l}$ of a buffer containing $50 \mathrm{mM}$ Tris $(\mathrm{pH}$ 7.5), $250 \mathrm{~mm} \mathrm{NaCl}, 0.5 \% \mathrm{NP}-40,1 \mathrm{~mm}$ DTT, $1 \mathrm{~mm} \mathrm{NaVO}_{4}, 10$ $\mathrm{mM} \mathrm{NaF}$, and $1 \times$ protease inhibitors (see above). $\mathrm{p} 130^{\mathrm{Rbr}-2}$ was recovered by immunoprecipitation with a monoclonal antibody directed against the HA epitope (12CA5, Babco), and precipitated proteins were analyzed by SDS-PAGE. In each case, quantitation of proteins present in unfractionated lysates confirmed that cyclins or CDK2 were present in excess to $\mathrm{p} 130^{\mathrm{Rbr}-2}$. Assay of cyclin $\mathrm{D} / \mathrm{CDK} 4$ kinase activity toward $\mathrm{p} 130^{\mathrm{Rbr}-2}$ was performed exactly as described (Ewen et al. 1993).

\section{Fluorescence in situ hybridization}

Plasmid preparations containing genomic subclones were labeled with digoxygenin and hybridized to synchronized normal lymphocyte preparations in a manner similar to that published previously (Demetrick and Beach 1993). Briefly, plasmid midipreps were purified on ion exchange columns (Quiagen). One microgram of plasmid containing the pl30 genomic insert was labeled with digoxygenin using a BRL nick-translation kit. Labeled probe was centrifuged over a 1-ml G-50 (Pharmacia) spin column. Fifty nanograms of probe in $50 \%$ formamide, $10 \%$ dextran sulfate, $2 \times$ SSC, and $1 \mathrm{mg} / \mathrm{ml}$ of sonicated human DNA in a total volume of $10 \mu \mathrm{l}$ was denatured by heating for $5 \mathrm{~min}$ at $85^{\circ} \mathrm{C}$, and suppressed for $15-30 \mathrm{~min}$ at $37^{\circ} \mathrm{C}$ before use. Metaphase chromosome spreads were prepared from normal lymphocytes stimulated with phytohemagglutinin and hybridized to probe essentially as described (Demetrick and Beach 1993).

Following hybridization, the slides were washed for $5 \mathrm{~min}$ in $50 \%$ formamide $/ 2 \times \operatorname{SSC}(3 \times)$ and $2 \times \operatorname{SSC}(3 \times)$ at $42^{\circ} \mathrm{C}$. The slides were then stained with $15 \mu \mathrm{g} / \mathrm{ml}$ of sheep antidigoxygenin (Boerhinger-Mannheim) and washed for $5 \mathrm{~min}$ each in three changes of $2 \times \mathrm{SSC} / 0.005 \%$ CHAPS (SC buffer), then incubated with a $1 / 40$ dilution of Cy3-conjugated donkey anti-sheep antibody (Jackson Immunoresearch). After the slides were washed, they were counterstained with DAPI and actinomycin D for DA-DAPI banding (Schweizer 1976). The slides were visualized utilizing a Nikon FXA microscope and a triple bandpass (FITC/ Texas red/DAPI, Chromo Technology, Inc.) filter. Hamster-human somatic cell hybrid DNA (BIOS Laboratories, New Haven, CT) was amplified by PCR using oligonucleotides directed against the human $\mathrm{p} 130^{\mathrm{Rbr}-2}$ cDNA sequence (ATAGGCCTTATTGATGGCT, GCTCCTTAAGGGAAAAGA). These primers give an amplified fragment of $\sim 0.8 \mathrm{~kb}$ when used in PCR reactions containing human genomic DNA. Although these oligonucleotides gave no specific amplified fragment when used in PCR reactions containing hamster DNA, an $0.8-\mathrm{kb}$ amplified band was observed in PCR reactions that included DNA prepared from somatic cell hybrid lines 967 and 1079. Both of these lines, but no others tested, contain human chromosome 16 .

\section{Acknowledgments}

We are indebted to Paul Bartel and Dr. Stan Fields (SUNY, Stony Brook) for providing plasmids and strains before publication and advice on the use of their two-hybrid system. Excellent technical assistance was provided by C. Gawel and S. Matsumoto. We thank Drs. Konstantin Galaktionov, Hui Zhang, Yue Xiong, and Tim Nilsen for helpful discussions and critical reading of the manuscript. Finally, we thank Dr. Stephen Gruenwald (Pharmingen) and Dr. Charles Sherr (St. Jude) for providing baculoviruses. G.J.H. is a postdoctoral fellow of the Damon Runyon-Walter Winchell Cancer Research Fund (DRG-1159). D.D. is supported by the Medical Research Council of Canada and The Alberta Heritage Fund for Medical Research. D.B. is an investigator of the Howard Hughes Medical Institute. This work was supported in part by the National Institutes of Health.

The publication costs of this article were defrayed in part by payment of page charges. This article must therefore be hereby marked "advertisement" in accordance with 18 USC section 1734 solely to indicate this fact.

\section{Note added in proof}

The sequence data described in this paper have been submitted to the EMBL/GenBank data libraries.

\section{References}

Altschul, S.F., W. Gish, W. Miller, E.W. Myers, and D.J. Lipman. 1990. Basic local alignment search tool. T. Mol. Biol. 215: 403-410.

Baldin, V., J. Lukas, M.J. Marcote, M. Pagano, and G. Draetta. 1993. Cyclin D1 is a nuclear protein required for cell cycle progression in $\mathrm{G}_{1}$. Genes \& Dev. 7: 812-821.

Bartel P.L., C.-T. Chien, R. Sternglanz, and S. Fields. 1993. Using the two hybrid system to detect protein-protein interactions. In Cellular interactions in development: $A$ practical approach (ed. D.A. Hartley), pp. 153-179. Oxford University Press, Oxford, UK.

Brizuela, L., G. Draetta, and D. Beach. 1987. p13sucl acts in the fission yeast cell division cycle as a component of the p34cdc2 protein kinase. EMBO I. 6: 3507-3514.

Carter, B.S., C.M. Ewing, W.S. Ward, B.F. Treiger, T.W. Aalders, J.A. Schalken, J.I. Epstein, and W.B. Isaacs. 1990. Allelic loss of chromosome $16 \mathrm{q}$ and $10 \mathrm{q}$ in human prostate cancer. Proc. Natl. Acad. Sci. 87: 8751-8755.

Chellapan, S.P., S. Hiebert, M. Mudryi, J.M. Horowitz, and J.R. Nevins. 1991. The E2F transcription factor is a cellular target for the RB protein. Cell 65: 1053-1061.

Cocks, B.G., G. Vairo, S.E. Bodrug, and J.A. Hamilton. 1992. Supression of growth factor-induced CYL-1 cyclin gene expression by antiproliferative agents. I. Biol. Chem. 267: 12307-12309.

Demetrick, D.J. and D.H. Beach. 1993. Chromosome mapping of human CDC25A and CDC25B phosphatases. Genomics 18: 144-147.

Devoto, S.H., M. Mudryj, J. Pines, T. Hunter, and J.R. Nevins. 1992. A cyclin A-protein kinase complex possesses sequence specific DNA binding activity: $\mathrm{p} 33 \mathrm{CDK} 2$ is a component of the E2F-cyclin A complex. Cell 68: 167-176.

Dowdy, S.F., P.W. Hinds, J. Louie, S.I. Reed, A. Arnold, and R.A. Wienberg. 1993. Physical interaction of the retinoblastoma protein with human D cyclins. Cell 73: 499-511.

Draetta, G. 1990. Cell cycle control in eukaryotes: Molecular mechanisms of cdc2 activation. Trends Biol. Sci. 15: 378- 
383.

Elledge, S. and M.S. Spottswood. 1991. A new human p34 protein kinase. CDK2, identified by complementation of a cdc28 mutation in Saccharomyces cerevisiae, is a homolog of Xenopus Egl. EMBO I. 9: 2653-2659.

Ewen, M.E., Y. Xing, J.B. Lawrence, and D. Livingston. 1991. Molecular cloning, chromosomal mapping, and expression of the cDNA for p107, a retinoblastoma gene product-related protein. Cell 66: 1155-1164.

Ewen, M.E., B. Faha, E. Harlow, and D. Livingston. 1992. Interaction of p107 with cyclin A independent of complex formation with viral oncoproteins. Science 255: 85-87.

Ewen, M.E., H.K. Sluss, C.J. Sherr, H. Matsushime, J. Kato, and D.M. Livingston. 1993. Functional interactions of the retinoblastoma protein with mammalian D-type cyclins. Cell 73: 487-497.

Faha, B., M.E. Ewen, L.-H. Tsai, D. Livingston, and E. Harlow. 1992. Interaction between human cyclin $A$ and adenovirus ElA-associated pl07 protein. Science 255: 87-90.

Faha, B., E. Harlow, and E. Lees. 1993. The Adenovirus E1Aassociated kinase consists of cyclin E-p33cdk2 and cyclin A-p33cdk2. I. Virol. 67: 2456-2465.

Field, J., J.-I. Nikawa, D. Broek, B. MacDonald, L. Rodgers, I.A. Wilson, R.A. Lemer, and M. Wigler. 1988. Purification of a RAS-responsive adenylyl cyclase complex from Saccharomyces cerevisiae by use of an epitope addition method. Mol. Cell. Biol. 8: 2159-2165.

Fields, S. and O. Song. 1989. A novel genetic sysem to detect protein-protein interactions. Nature 340: 245-246.

Fitch, I., C. Dahmann, U. Surana, A. Amon, K. Naysmith, L. Goetsch, B. Byers, and B. Futcher. 1992. Characterization of four B-type cyclin genes of the budding yeast Saccharomyces cerevisiae. Mol. Cell. Biol. 3: 805-818.

Goodrich, D.W. and W.-H. Lee. 1993. Molecular characterization of the retinoblastoma susceptibility gene. Biochim. Biophys. Acta 1155: 43-61.

Gu, W., J.W. Schneider, G. Condorelli, S. Kaushal, V. Mahdavi, and B. Nadal-Ginard. 1993. Interaction of myogenic factors and the retinoblastoma protein mediates muscle cell commitment and differentiation. Cell 72: 309-324.

Guan, K.-L. and J.E. Dixon. 1991. Eukaryotic proteins expressed in Escherichia coli: An improved thrombin cleavage and purification procedure of fusion proteins with glutathione S-transferase. Anal. Biochem. 192: 262-267.

Hannon, G.J., P.A. Maroney, D.G. Ayers, J.S. Shambaugh, and T.W. Nilsen. 1990. Transcription of a nematode transspliced leader RNA requires internal elements for both initiation and 3' end formation. EMBO F. 9: 3667-3673.

Harlow, E., P. Whyte, R. Franza, and C. Schley. 1986. Association of adenovirus early-region $1 \mathrm{~A}$ proteins with cellular polypeptides. Mol. Cell. Biol. 6: 1579-1589.

Hiebert, S.W., S.P. Chellapan, J.M. Horowitz, and J.R. Nevins. 1992. The interaction of RB with E2F coincides with an inhibition of the transcriptional activity of E2F. Genes \& Dev. 6: $177-185$.

Hu, Q., N. Dyson, and E. Harlow. 1990. The regions of the retinoblastoma protein needed for binding to adenovirus E1A or SV40 large T antigen are common sites for mutations. EMBO I. 9: 1815-1822.

$\mathrm{Hu}$, Q., C. Bautista, G.M. Edwards, D. Defeo-Jones, R.E. Jones, and E. Harlow. 1991. Antibodies specific for the human retinoblastoma protein identify a family of related polypeptides. Mol. Cell. Biol. 11: 5792-5799.

Huang, S., N.P. Wang, B.Y. Tseng, W.H. Lee, and E.H. Lee. 1990. Two distinct and frequently mutated regions of retinoblastoma protein are required for binding to SV40 $\mathrm{T}$ antigen.
EMBO I. 9: 1815-1822.

Inaba, T., H. Matsushime, M. Valentine, M.F. Roussel, C.J. Sherr, and A.T. Look. 1992. Genomic organization, chromosomal localization, and independent expression of human cyclin D genes. Genomics 13: 565-574.

Isaacs, W.B. and B.S. Carter. 1991. Genetic changes associated with prostate cancer in humans. Cancer Surv. 11: 15-24.

Kaelin, W.G.J., M.E. Ewen, and D.M. Livingston. 1990. Definition of the minimal simian virus 40 large $T$ antigen and adenovirus E1A binding domain in the retinoblastoma gene product. Mol. Cell. Biol. 10: 3761-3769.

Kaelin, W.G.J., D.C. Pallas, J.A. DeCaprio, F.J. Kaye, and D.M. Livingston. 1991. Identification of cellular proteins that can interact specifically with the T/E1A-binding region of the retinoblastoma gene product. Cell 64: 521-532.

Kaneko, Y., C. Homma, N. Maseki, M. Sakurai, and J. Hata. 1991. Correlation of chromosome abnormalities with histological and clinical features in Wilms' and other childhood renal tumors. Cancer Res. 51: 5937-5942.

Kato, J., H. Matsushime, S.W. Hiebert, M.E. Ewen, and C.J. Sherr. 1993. Direct binding of cyclin $D$ to the retinoblastoma gene product $(\mathrm{pRB})$ and $\mathrm{pRB}$ phosphorylation by the cyclindependent kinase CDK4. Genes \& Dev. 7: 331-342.

Kaye, F.J., R.A. Kratzke, J.L. Gerster, and J.M. Horowitz. 1990. A single amino acid substitution results in a retinoblastoma protein defective in phosphorylation and oncoprotein binding. Proc. Natl. Acad. Sci. 87: 6922-6926.

Lees, E., B. Faha, V. Dulic, S.I. Reed, and E. Harlow. 1992. Cyclin E/CDK2 and cyclin A/CDK2 kinases associate with pl07 and E2F in a temporally distinct manner. Genes \& Dev. 6: $1874-1885$.

Lew, D.J., V. Dulic, and S.I. Reed. 1991. Isolation of three novel cyclins by rescue of $\mathrm{G} 1$ cyclin $(\mathrm{Cln})$ function in yeast. Cell 66: 1197-1206.

Matsushime, H., M.F. Roussel, R.A. Ashmum, and C.J. Sherr. 1991. Colony-stimulating factor 1 regulates novel cyclins during the G1 phase of the cell cycle. Cell 66: 701-713.

Maw, M.A., P.E. Grundy, L.J. Millow, M.R. Eccles, R.S. Dunn, P.J. Smith, A.P. Feinberg, D.J. Law, M.C. Paterson, and P.E. Telzerow. 1992. A third Wilms' tumor locus on chromosome 16q. Cancer Res. 52: 3094-3098.

Mitchell, E.L. and M.F. Santibanez-Koref. 1990. 1 pl3 is the most frequently involved band in structural chromosomal rearrangements in human breast cancer. Genes Chromosomes Cancer 2: 278-289.

Mudryi, M., S.H. Devoto, S.W. Heibert, T. Hunter, J. Pines, and J.R. Nevins. 1991. Cell cycle regulation of the E2F transcription factor involves interaction with cyclin A. Cell 65: 1243-1253.

Muller, R., D. Mumberg, and F.C. Lucibello. 1993. Signals and genes in the control of cell-cycle progression. Biochim. Biophys. Acta 1155: 151-179.

Ohtsubo, M. and J.M. Roberts. 1993. Cyclin-dependent regulation of Gl in mammalian fibroblasts. Science 259: 19081912.

Peeper, D.S., L.L. Parker, M.E. Ewen, M. Toebes, F.L. Hall, M. $\mathrm{Xu}$, A. Zantema, A.J. van der Eb, and H. Piwnica-Worms. 1993. A- and B-type cyclins differentially modulate substrate specificity of cyclin-cdk complexes. EMBO J. 12: 1947-1954.

Richardson, H.E., C. Wittenberg, F. Cross, and S.I. Reed. 1989. An essential G1 function for cyclin-like proteins in yeast. Cell 59: 1127-1133.

Richardson, H.E., C.S. Stueland, J. Thomas, P. Russell, and S.I. Reed. 1990. Human cDNA encoding homologs of the small p34cdc28/cdc2-associated protein of Saccharomyces cerevisiae and Schizosaccharomyces pombe. Genes \& Dev. 
4: 1332-1344.

Richardson, H., D.J. Lew, M. Henze, K. Sugimoto, and S.I. Reed. 1992. Cyclin-B homologs in Saccharomyces cerevisiae function in S phase and in $G_{2}$. Genes \& Dev. 6: 2021-2034.

Sato, T., A. Tanigami, K. Yamakawa, F. Akiyama, F. Kasumi, G. Sakamoto, and Y. Nakamura. 1990. Allelotype of breast cancer: Cumulative allele losses promote tumor progression in primary breast cancer. Cancer Res. 50: 7184-7189.

Sato, T., F. Akiyama, G. Sakamoto, F. Kasumi, and Y. Nakamura. 1991. Accumulation of genetic alterations and progression of primary breast cancer. Cancer Res. 51: 5794 5799.

Schweizer, D. 1976. Reverse fluorescent chromosome banding with chromomycin and DAPI. Chromosoma 58: 307-324.

Sherr, C.J. 1993. Mammalian Gl cyclins. Cell 73: 1059-1065.

Slater, R.M. and M.M. Mannens. 1992. Cytogenetics and molecular genetics of Wilms' tumor of childhood. Cancer Genet. Cytogenet. 61: 111-121.

Thomas, G.A. and C. Raffel. 1991. Loss of heterozygosity on 6q, $16 q$ and $17 p$ in human central nervous system primitive neuroectodermal tumors. Cancer Res. 51: 639-643.

Tsai, L.-H., E. Harlow, and M. Meyerson. 1991. Isolation of the human CDK2 gene that encodes the cyclin A- and adenovirus E1A-associated p33 kinase. Nature 353: 174-177.

Wagner, S. and M.R. Green. 1991. A transcriptional tryst. Nature 352: 189-190.

Weinberg, R. 1992. The retinoblastoma gene and gene product. Cancer Surv. 12: 43-57.

Weintraub, H., R. Davis, S. Tapscott, M. Thayer, M. Krause, R. Benezra, and A. Lassar. 1991. The myoD gene family: Nodal point during specification of the muscle cell lineage. Science 251: 761-766.

Weintraub, S.J., C.A. Prater, and D.C. Dean. 1992. Retinoblastoma protein switches the E2F site from a positive to a negative element. Nature 358: 259-261.

Wittenberg, C. and S.I. Reed. 1989. Conservation of function and regulation within the $\mathrm{cdc} 28 / \mathrm{cdc} 2$ protein kinase family: Characterization of the human cdc2Hs protein kinase in Saccharomyces cerevisiae. Mol. Cell. Biol. 9: 4064-4068.

Won, K.-A., Y. Xiong, D. Beach, and M.Z. Gilman. 1992. Growth-regulated expression of D-type cyclin genes in human diploid fibroblasts. Proc. Natl. Acad. Sci. 89: 99109914.

Xiong, Y., H. Zhang, and D. Beach. 1993. Subunit rearrangent of cyclin-dependent kinases is associated with cellular transformation. Genes \& Dev. 7: 1572-1583.

Yokata, J., T. Sugimura, and M. Terada. 1991. Chromosomal localization of putative tumor-suppressor genes in several human cancers. Environ. Health Perspect. 93: 121-123.

Zhang, W.D., S. Hirohashi, H. Tsuda, Y. Shimosato, J. Yokota, M. Terada, and T. Sugimura. 1990. Frequent loss of heterozygosity on chromosomes 16 and 4 in human hepatocellular carcinoma. Ipn. I. Cancer Res. 81: 108-111.

Zhu, L., S. van der Heuvel, K. Helin, A. Fattaey, M. Ewen, D. Livingston, N. Dyson, and E. Harlow. 1993. Inhibition of cell proliferation by $\mathrm{p} 107$, a relative of the retinoblastoma protein. Genes \& Dev. 7: 1111-1125. 


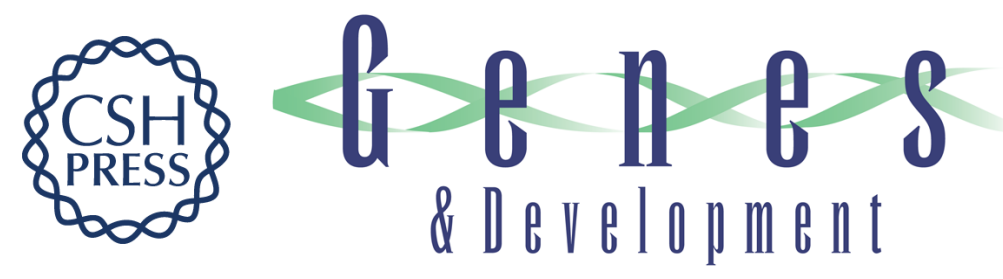

\section{Isolation of the Rb-related p130 through its interaction with CDK2 and cyclins.}

G J Hannon, D Demetrick and D Beach

Genes Dev. 1993, 7:

Access the most recent version at doi:10.1101/gad.7.12a.2378

References This article cites 64 articles, 27 of which can be accessed free at: http://genesdev.cshlp.org/content/7/12a/2378.full.html\#ref-list-1

License

Email Alerting

Receive free email alerts when new articles cite this article - sign up in the box at the top Service right corner of the article or click here.

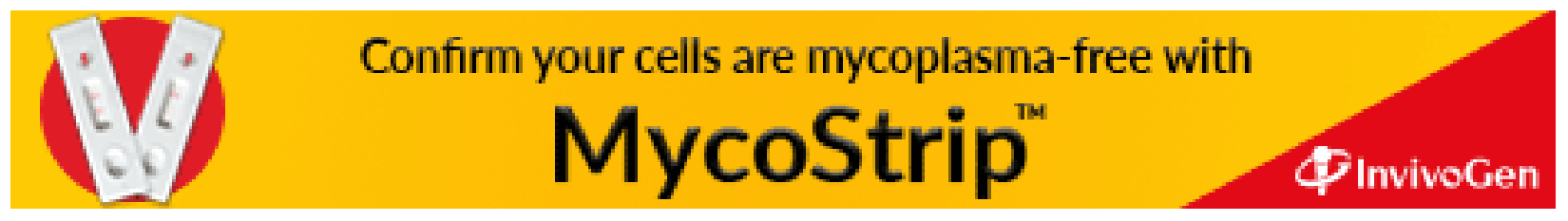

